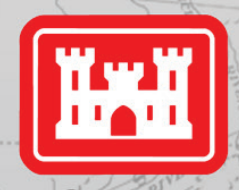

US Army Corps of Engineers ${ }_{\mathbb{Q}}$

\title{
2015 Updated Atlas of U.S. Army Corps of Engineers Historic Daily Tide Data in Coastal Louisiana
}

MRG\&P Report No. 14 • November 2017

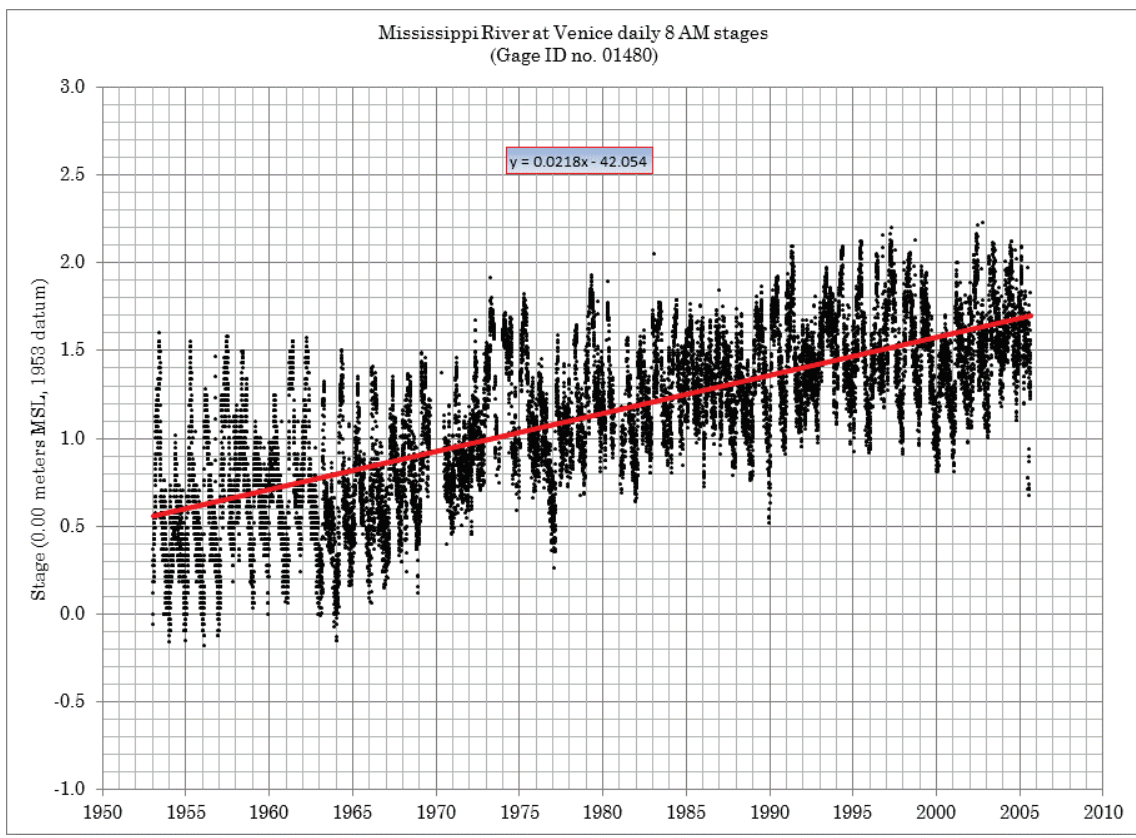

$\mathrm{MRG \& P}$

Mississippi River Geomorphology \& Potamology Program 


\section{Updated Atlas of U.S. Army Corps of Engineers Historic Daily Tide Data in Coastal Louisiana}

Will Veatch

U.S. Army Corps of Engineers, New Orleans District 7400 Leake Avenue

New Orleans, LA 70118

Final report

Approved for public release; distribution is unlimited.

Prepared for U.S. Army Corps of Engineers, Mississippi Valley Division Mississippi River Geomorphology and Potamology Program 1400 Walnut Street Vicksburg, MS 39180

Under Project 127672, "Tide Atlas Update” 


\section{Abstract}

In 2010, data were analyzed from 19 U.S. Army Corps of Engineers (USACE) gages to develop the USACE Tide Gage Atlas for Coastal Louisiana. The purpose of this document was to develop a useful tool for analyzing the sea level change trends in the coastal areas of Louisiana, where some of the highest relative sea level rise rates in the United States are observed (because of the significant subsidence in this region). The data were referenced to a common gage datum, analyzed for shifts, and any known adjustments removed. This 2015 update revised five of the nineteen original gages by extending the record of gage data and reapplying the linear trend. Eleven new gages were added, expanding the atlas to a total of thirty gages. The new data were evaluated in the same manner as the previously studied gages: adjustments were made to remove shifts in the data, river discharge influences were removed where necessary, and linear trends were applied. Continuous revisions of the atlas are intended to not only keep sea level change trends updated but also to expand data resources for ongoing and future projects.

DISCLAIMER: The contents of this report are not to be used for advertising, publication, or promotional purposes. Citation of trade names does not constitute an official endorsement or approval of the use of such commercial products. All product names and trademarks cited are the property of their respective owners. The findings of this report are not to be construed as an official Department of the Army position unless so designated by other authorized documents. 


\section{Contents}

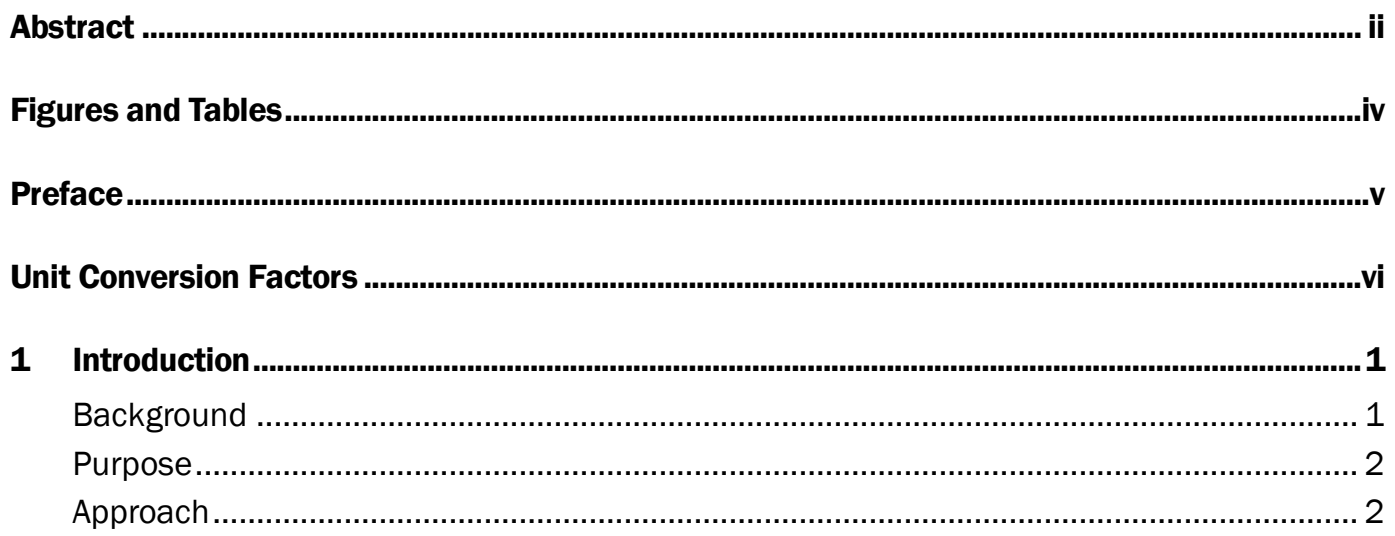

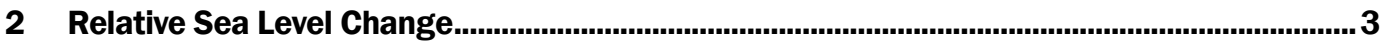

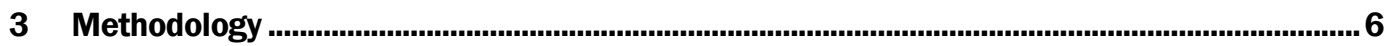

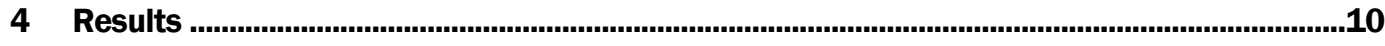

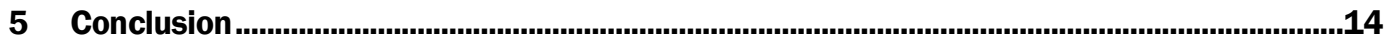

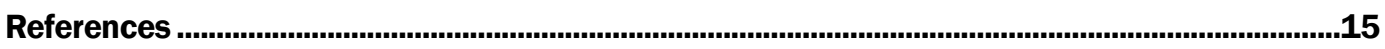

Appendix: USACE Gages Daily Stage Graphs and Linear Trends .................................................16

Report Documentation Page 


\section{Figures and Tables}

\section{Figures}

Figure 1. Map of the Coastal Vulnerability Index (CVI) for the U.S. Gulf Coast. (Source: http://pubs.usgs.gov/of/2000/of00-179/)...

Figure 2. Reproduction of IPCC (2007) figure showing decadal variability in eustatic sea level rates. (Source: IPCC Fourth Assessment Report: Climate Change 2007 (AR4), IPCC [2007]; http://www.ipcc.ch/index.htm).

Figure 3. Estimated future sea level rise projections.

Figure 4. Example of record with unknown gage shift. .................................................................... 6

Figure 5. Example of record with gage shift removed........................................................................

Figure 6. Example plot demonstrating procedure to extract tidal signal from observed

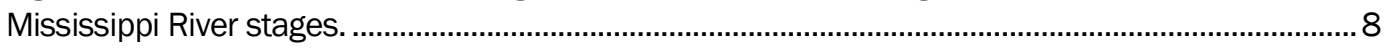

Figure 7. Example stage record and resultant synthetic tide from the tide extraction process for a portion of the Carrollton daily stage record

Figure 8. Locations of USACE gages analyzed for relative sea level trends in Southwest Louisiana.

Figure 9. Locations of USACE gages analyzed for relative sea level trends in Southeast Louisiana.

\section{Tables}

Table 1. Summary table of 2015 Updated Relative Sea Level Trends for USACE gages. 


\section{Preface}

The work documented in this report was conducted as part of the Mississippi River Geomorphology \& Potamology (MRG\&P) Program, Project 127672; "Tide Atlas Update." The MRG\&P is part of the Mississippi River and Tributaries Program and is managed by the U.S. Army Corps of Engineers (USACE), Mississippi Valley Division (MVD), and Districts. At the time of publication, the MRG\&P Technical Director was Dr. Ty Wamsley. The MVD Commander was MG Richard G. Kaiser. The MVD Director of Programs was Mr. James A. Bodron.

Mississippi River engineering direction and policy advice were provided by the Mississippi River Commission. The Commission members were MG Kaiser, USACE; the Honorable Sam E. Angel; the Honorable R. D. James; the Honorable Norma Jean Mattei, Ph.D.; RDML Shepard Smith, National Oceanic and Atmospheric Administration; BG Mark Toy, USACE; and COL Paul E. Owen, USACE.

The investigation was conducted by the New Orleans District (MVN). Funding for the study was provided by MVD. Direct supervision was provided by Mr. David Ramirez, Chief of the Water Management and River Engineering Section.

The Commander of MVN was COL Michael N. Clancy. 


\section{Unit Conversion Factors}

\begin{tabular}{|l|l|l|}
\hline Multiply & By & To Obtain \\
\hline cubic feet & 0.02831685 & cubic meters \\
\hline feet & 0.3048 & meters \\
\hline inches & 0.0254 & meters \\
\hline
\end{tabular}




\section{Introduction}

\section{Background}

In recent years, a growing public interest has developed regarding the alarming rates of land loss in coastal Louisiana, especially since Hurricanes Katrina and Rita devastated Louisiana's coastal marshes and communities. An understanding of the contributions of land subsidence (isostatic) and global sea level rise (eustatic) to Louisiana's wetland loss is crucial to the success of any future plans designed to protect coastal communities (Gonzalez and Tornqvist 2006). The Louisiana coast's geography makes it especially vulnerable to the effects of relative sea level rise (RSLR) (Figure 1).

Figure 1. Map of the Coastal Vulnerability Index (CVI) for the U.S. Gulf Coast. (Source: http://pubs.usgs.gov/of/2000/of00-179/)

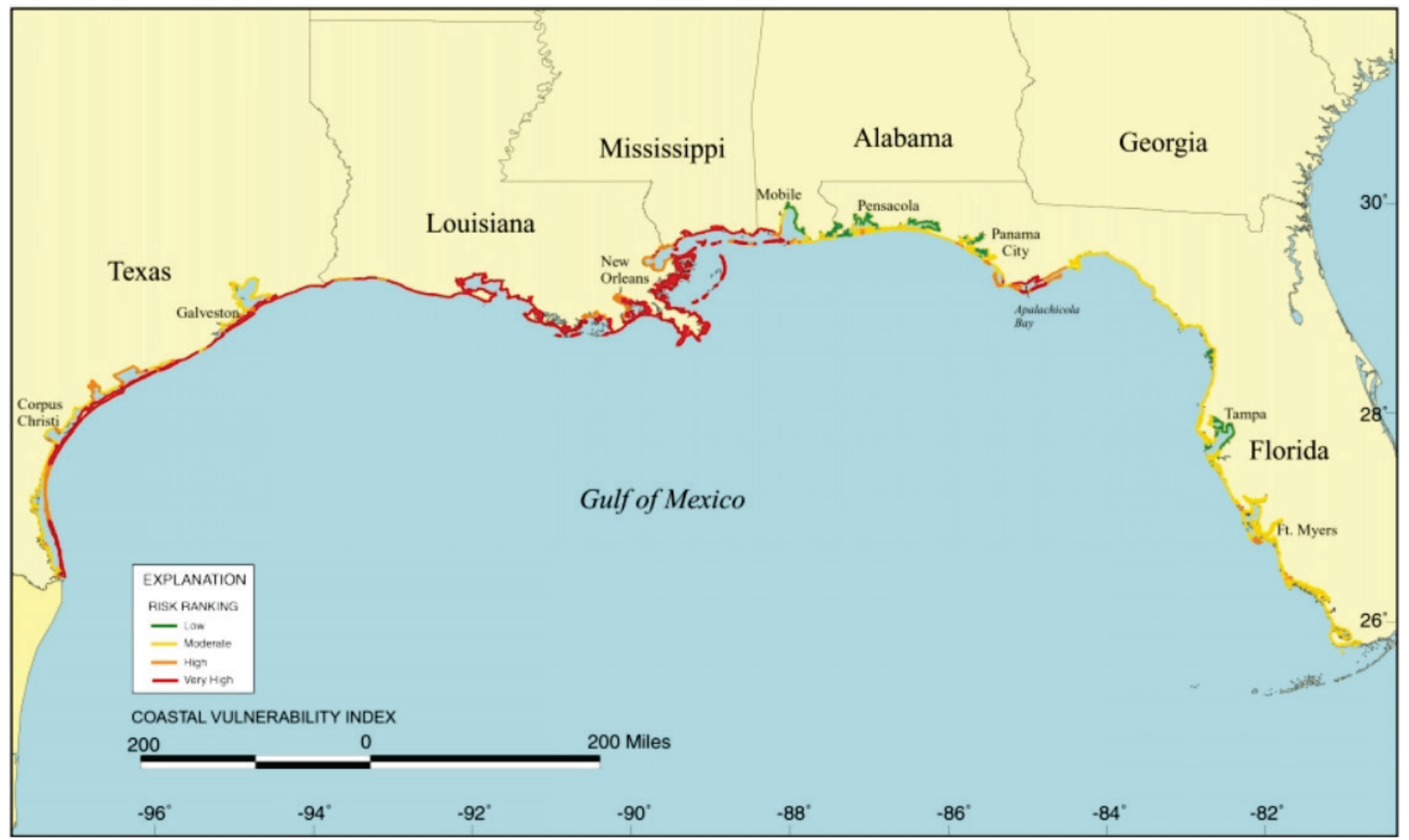

The U.S. Army Corps of Engineers (USACE), New Orleans District (CEMVN), has historically collected daily water level data from various water bodies, rivers, and streams throughout southern Louisiana. Some of these gages have recorded data in tidal areas and have long periods of record with some exceeding 50 years of collected data. To develop 
estimates of relative sea level rise for coastal Louisiana projects, CEMVN engaged in a study of stage data compiled at various coastal data collection sites in 2010. In 2015, the New Orleans district updated the report to incorporate gage data between 2010 and 2014 for the previously studied gages and to include new gages that formerly did not have the required 40 years of data. The new gages were selected by CEMVN staff based on those with sea level change estimates that would prove useful in informing nearby projects. The Tide Gage Atlas of Coastal Louisiana now contains RSLR trends for 30 USACE gages.

\section{Purpose}

The purpose of the analyses conducted for this study was to determine the RSLR at particular gage sites. This necessitated having all recorded stages for the gages in a common vertical datum. However, records for all datum shifts and corrections applied to the gage records were not always available. In those situations, vertical shifts in the data had to be determined by other means.

\section{Approach}

The Approach is addressed in Chapter 3 Methodology. 


\section{Relative Sea Level Change}

Relative mean sea level change at a particular location includes the cumulative effects of global (eustatic) sea level change, regional variability from the global rate in semi-enclosed basins such as the Gulf of Mexico, and any local change in land elevation (isostatic movement). The longterm causes of relative mean sea level change are six fold and include eustatic rise, crustal subsidence, seismic subsidence, auto-subsidence, man-made subsidence, and variations due to climatic fluctuations (NRC 1987). Coastal Louisiana has some of the highest regional subsidence rates in the United States and consequently is subject to some of the highest rates of RSLR.

The data presented here are intended to represent the total RSLR experienced at a particular location. No attempt is made to extract the various components comprising relative sea level change or to provide further analysis of the data other than what was recorded at the site. Estimates of vertical land movement may be made by subtracting the eustatic sea level rise rate from the data. However, due to the inherent temporal and regional variability of the eustatic sea level rise rate, that attempt was not made in the previous atlas nor is it made in this updated atlas.

Estimates of historic eustatic sea level rise rates may be found in the literature. One such estimate is in the Intergovernmental Panel on Climate Change (IPCC) Fourth Assessment Report: Climate Change 2007 (AR4) (IPCC 2007), which suggests a rate of $+1.8 \pm 0.5$ millimeters $(\mathrm{mm}) /$ year $^{-1}$ for the period of 1961 to 2003 and $+1.7 \pm 0.5 \mathrm{~mm} \mathrm{yr}^{-1}$ for the twentieth century. However, the data upon which those estimates are based are highly variable by decade. For example, a rate of $3.1 \pm 0.7 \mathrm{~mm}$ year $^{-1}$ has been estimated for the period 1993 to 2003, significantly higher than the average rate. It is unknown whether the higher rate during the latest decade in the analysis is due to decadal variability or an increase in the longer-term trend. Figure 2 is a reproduction of a figure from the IPCC 2007 report that shows the high variability in global sea level change over time. 
Figure 2. Reproduction of IPCC (2007) figure showing decadal variability in eustatic sea level rates. (Source: IPCC Fourth Assessment Report: Climate Change 2007 (AR4), IPCC [2007]; http://www.ipcc.ch/index.htm)

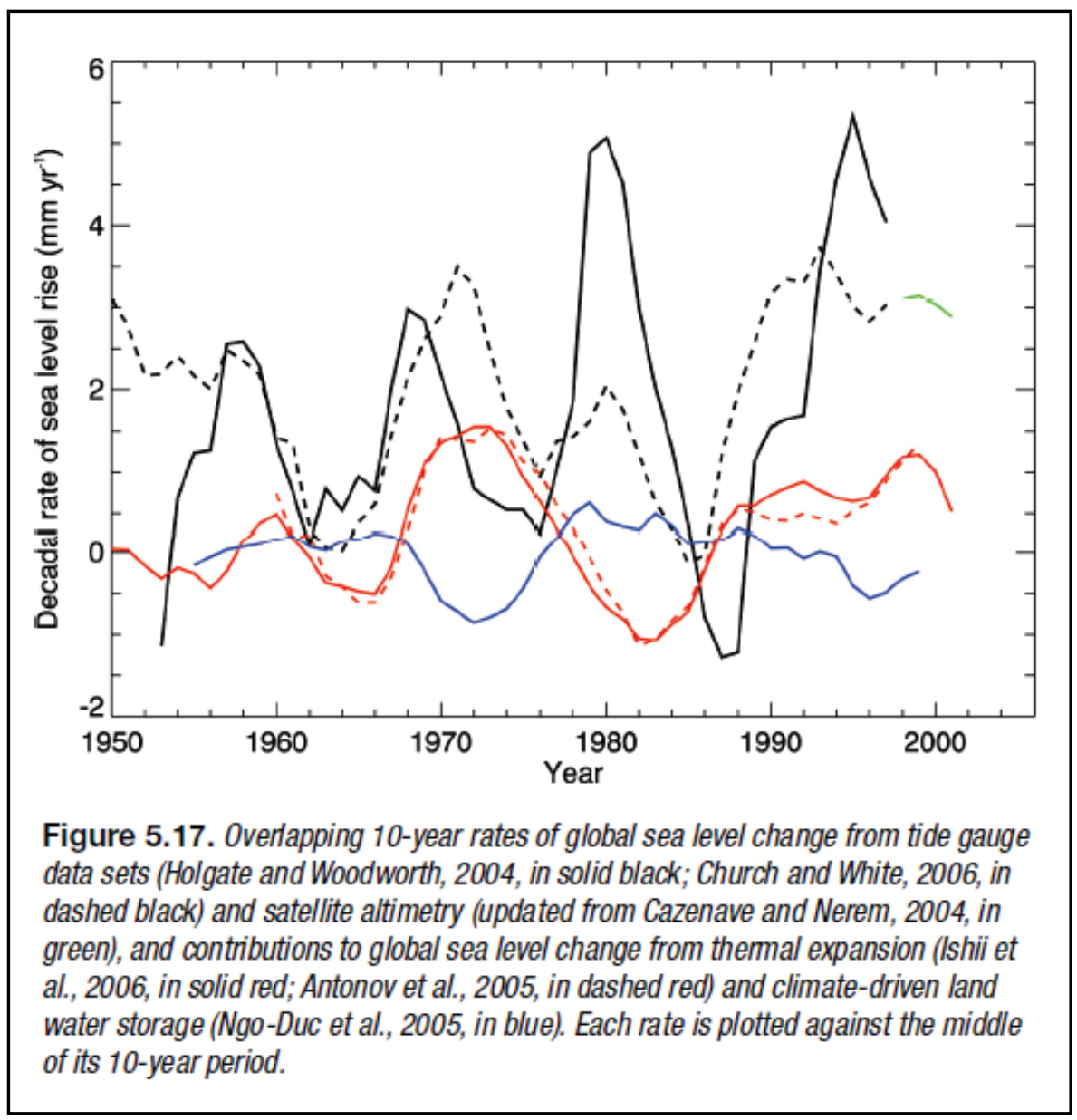

Projections of estimated sea level rise were also generated during the update to the Tide Gage Atlas of Coastal Louisiana using guidance from ER 1100-2-8162, Incorporating Sea Level Changes in Civil Works Programs (USACE 2013). The new regulation, published in 2013, dictates generating three curves for future projections: low (historic), intermediate, and high rate of sea level rise. The low-rate curve is an extrapolation of the historic trend while the other curves include an acceleration factor following the equation:

$$
E\left(t_{2}\right)-E\left(t_{1}\right)=0.0017\left(t_{2}-t_{1}\right)+b\left(t_{2}^{2}-t_{1}^{2}\right)
$$

where:

$$
\begin{aligned}
& t_{1}=\text { time in years from } 1992 \text { to the start year } \\
& t_{2}=\text { time in years from } 1992 \text { to the projection year }
\end{aligned}
$$


$\mathrm{b}=$ the intermediate or high acceleration factor, $2.71 \mathrm{E}-05$ and $1.130 \mathrm{OE}-04$, respectively.

An example of the projection graph generated is given in Figure 3.

Figure 3. Estimated future sea level rise projections.

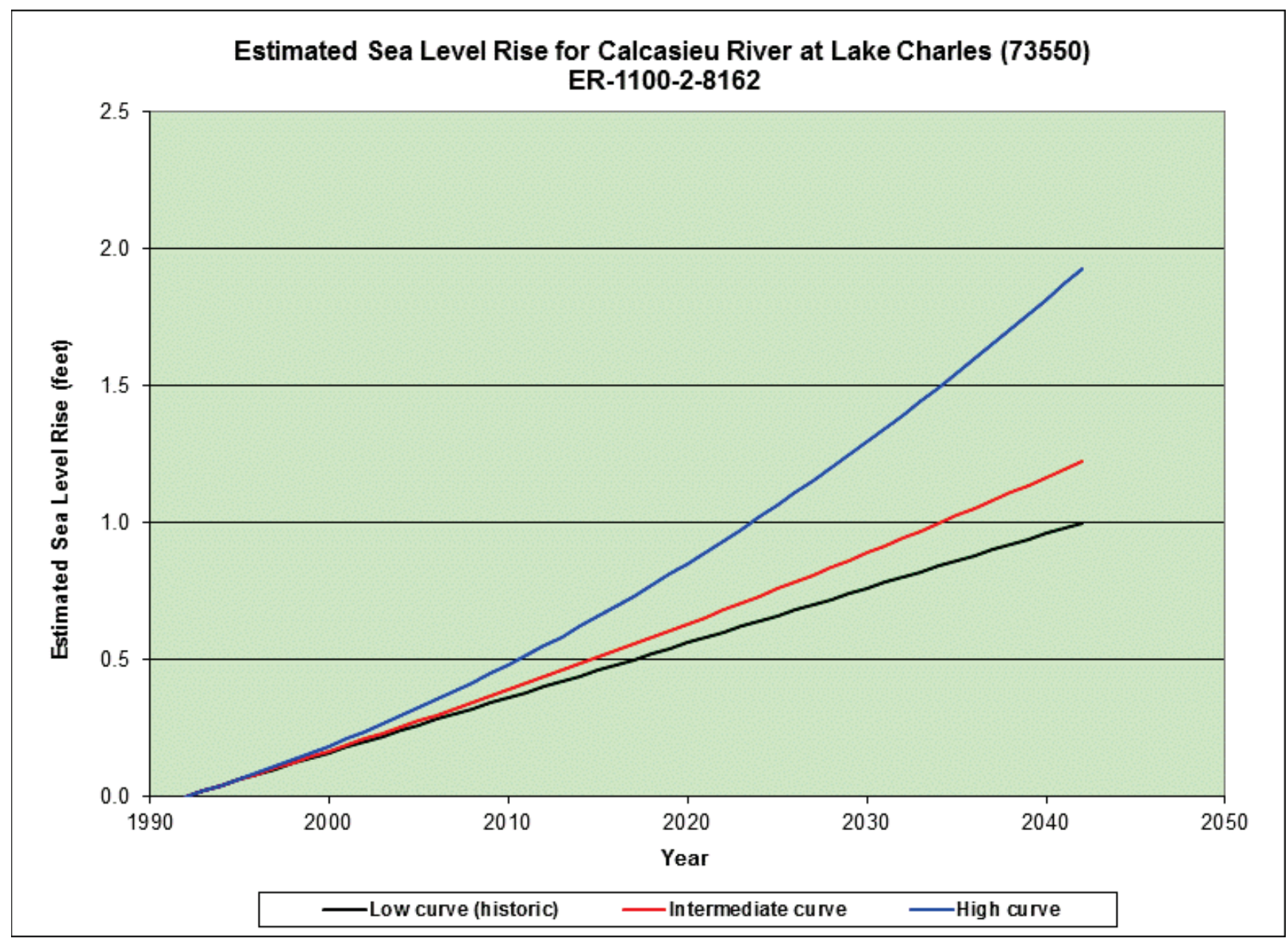




\section{Methodology}

One technique used to determine vertical gage adjustments was by comparison of the data with data recorded at a nearby gage site that was not shifted during the time frame of the suspected shift. Plotting the two gage records together provided a means of determining significant shifts by visual inspection and correlating the suspected vertical shift amount to the known nearby gage that was not shifted.

Some gage shifts were estimated by determining the linear trend of the data sets before and after the shift was applied, usually during a protracted period of missing data, and adjusting the data after the data gap so that the linear trends matched through the data gap. In other words, the linear equations of the two trends were solved for the variable $y$ using the same variable $x$ representative of the time (or year) when the shift was thought to have been applied. The resulting difference is the value of the vertical shift applied at time $x$ (Figures 4 and 5).

Figure 4. Example of record with unknown gage shift.

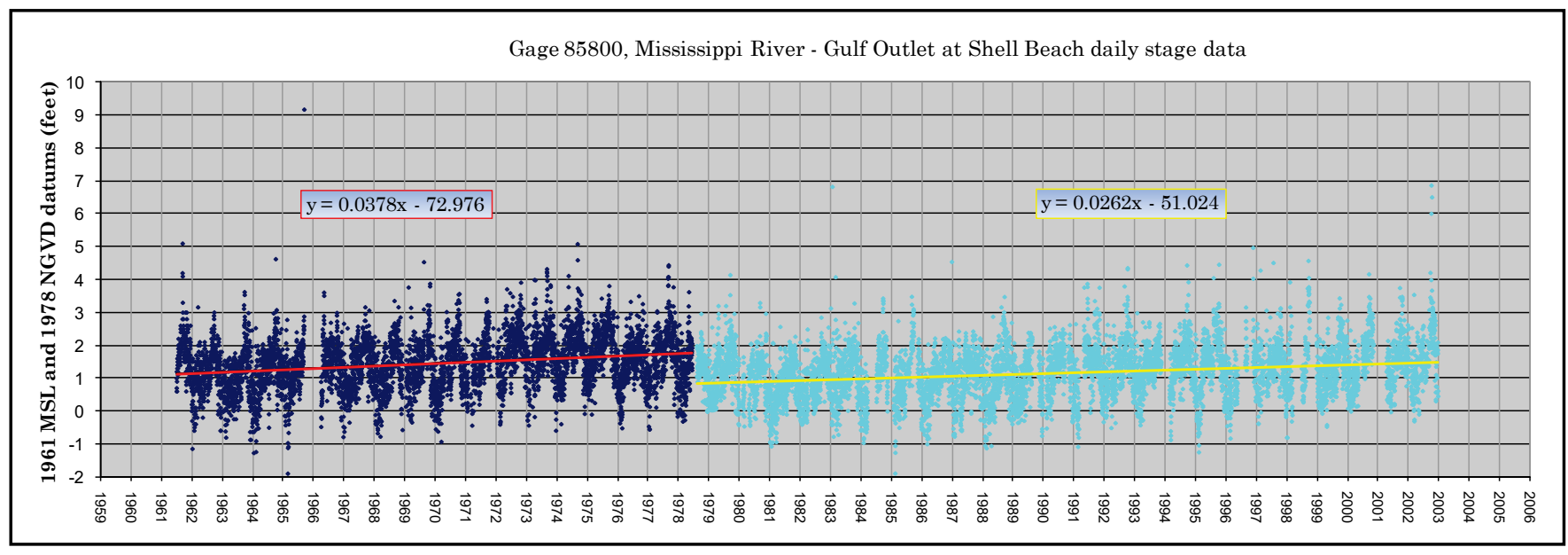


Figure 5. Example of record with gage shift removed.

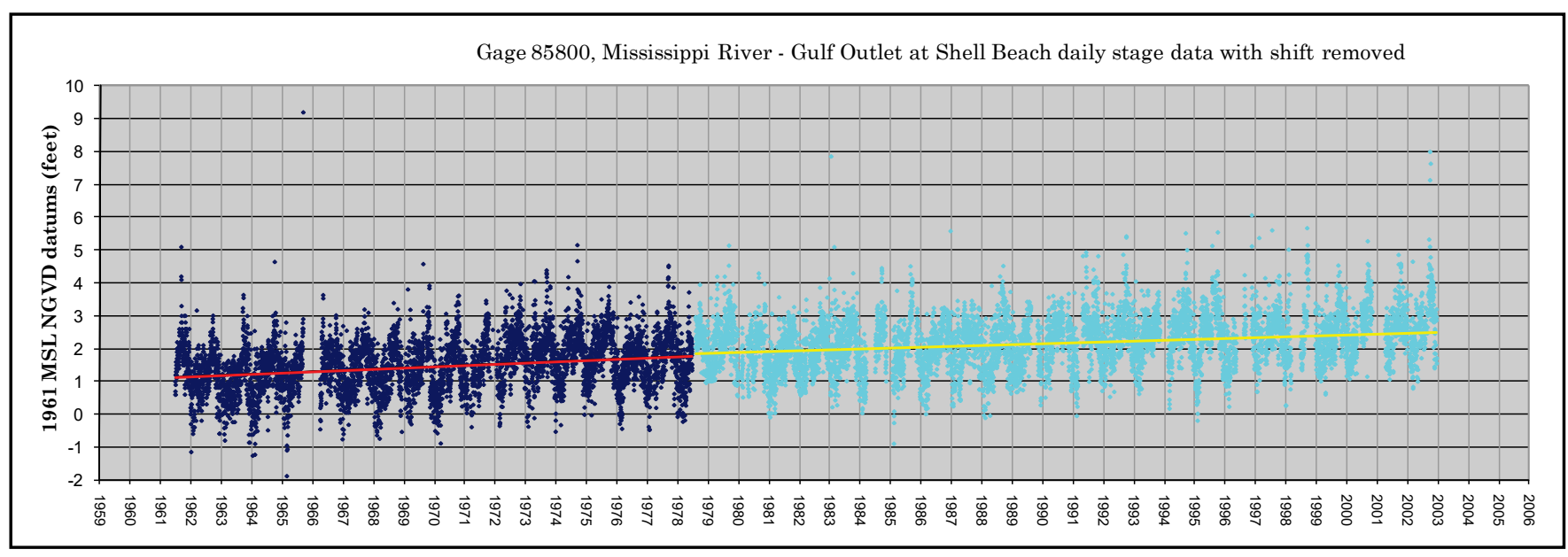

A portion of the variability in stage for gages on the Mississippi River is a result of variable river discharge. To extract that portion of the stage record that is due to tidal effects only, a special analysis was conducted on the Carrollton, Inner Harbor Navigation Canal (IHNC) Lock, West Pointe a la Hache, and Venice gages because these gages are located on the river, and a significant portion of the variability in their stage records is due to river discharge rather than coastal influences. The analysis consisted of comparing observed stage data to the stage derived from a 6-year moving linear stage-discharge relationship between stage at the local gage of interest and Mississippi River discharge measured at Tarbert Landing near the Old River Control Complex. Adjustments were made to the flow data to account for withdrawals at the Bonnet Carré and Morganza Floodways as well as temporal shifts applied to account for travel time from Tarbert Landing to the gage site being analyzed.

As an example, the procedure is shown here for the Carrollton gage analysis. First, Tarbert Landing discharges were translated to the Carrollton gage site by accounting for any withdrawals made at the Bonnet Carré and Morganza Floodways, and the discharges were shifted 1 day ahead to account for travel time from Tarbert Landing to Bonnet Carré. Daily stage/discharge relationships were developed using a moving \pm 3 years moving linear trend. The resultant stage/discharge points are shown in Figure 6 for 1 July 1975. 
Figure 6. Example plot demonstrating procedure to extract tidal signal from observed Mississippi River stages.

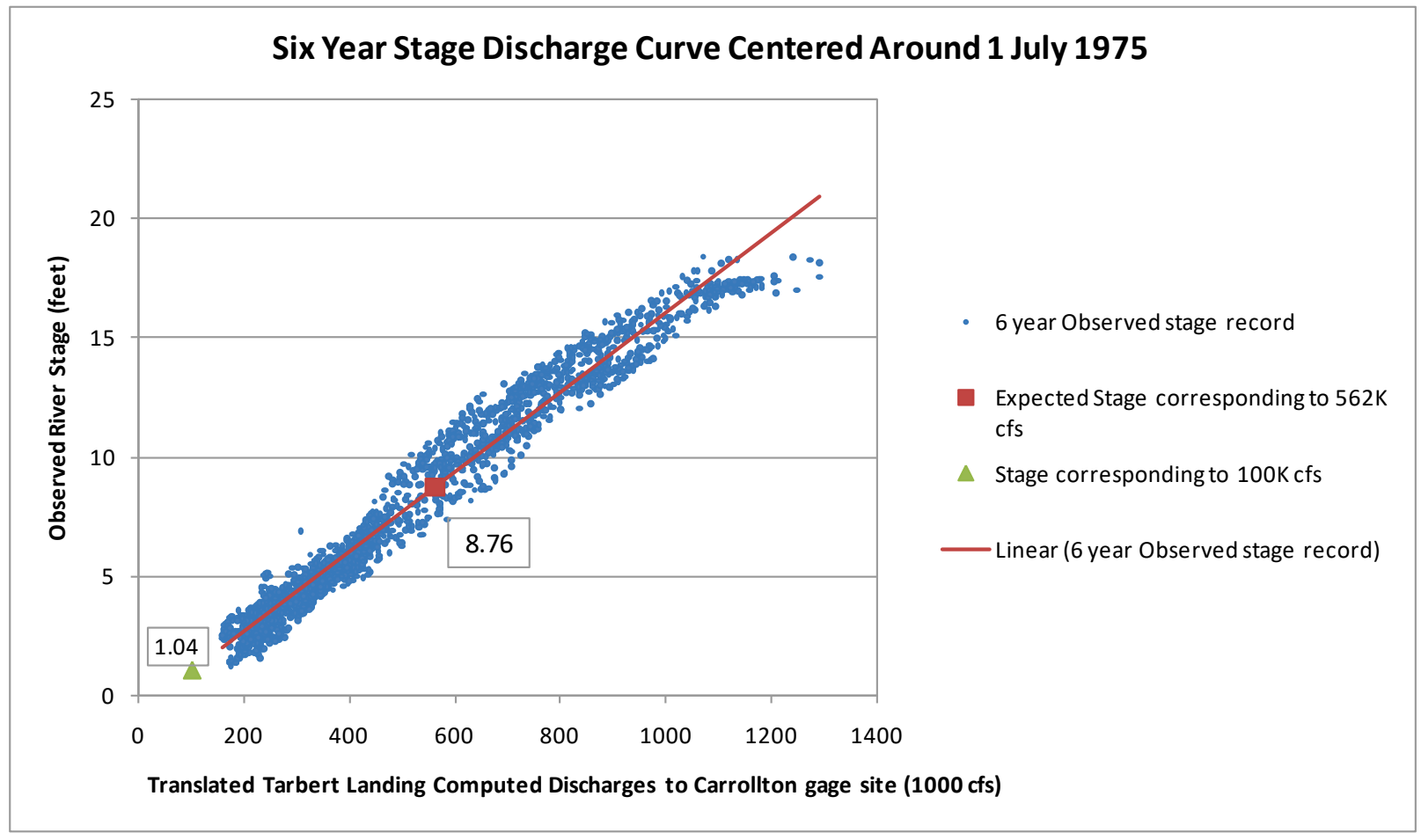

The expected stage from this linear stage/discharge relationship for the corresponding Carrollton discharge on 1 July 1975 of $562 \mathrm{~K}$ cubic feet per second (cfs) was 8.76 feet (ft). The stage corresponding to a base flow of $100 \mathrm{~K}$ cfs, or $1.04 \mathrm{ft}$, was subtracted from this stage to get a stage adjustment of $7.72 \mathrm{ft}$, which is considered to be an estimate of that portion of the stage record attributable to Mississippi River discharge variance. The use of $100 \mathrm{~K}$ cfs as the base flow was selected because that is the lowest computed discharge on the Mississippi River during the period of record. The daily stage adjustment was then subtracted from the observed stage to build the daily synthetic tide record (i.e., for 1 July 1975, the result is $9.78 \mathrm{ft}$ minus $7.72 \mathrm{ft}$ or $2.06 \mathrm{ft}$ ). The slope of this synthetic tide record is considered to represent the RSLR for that particular gage. The resultant synthetic tide is shown in Figure 7 for a portion of the Carrollton stage record. 
Figure 7. Example stage record and resultant synthetic tide from the tide extraction process for a portion of the Carrolton daily stage record.

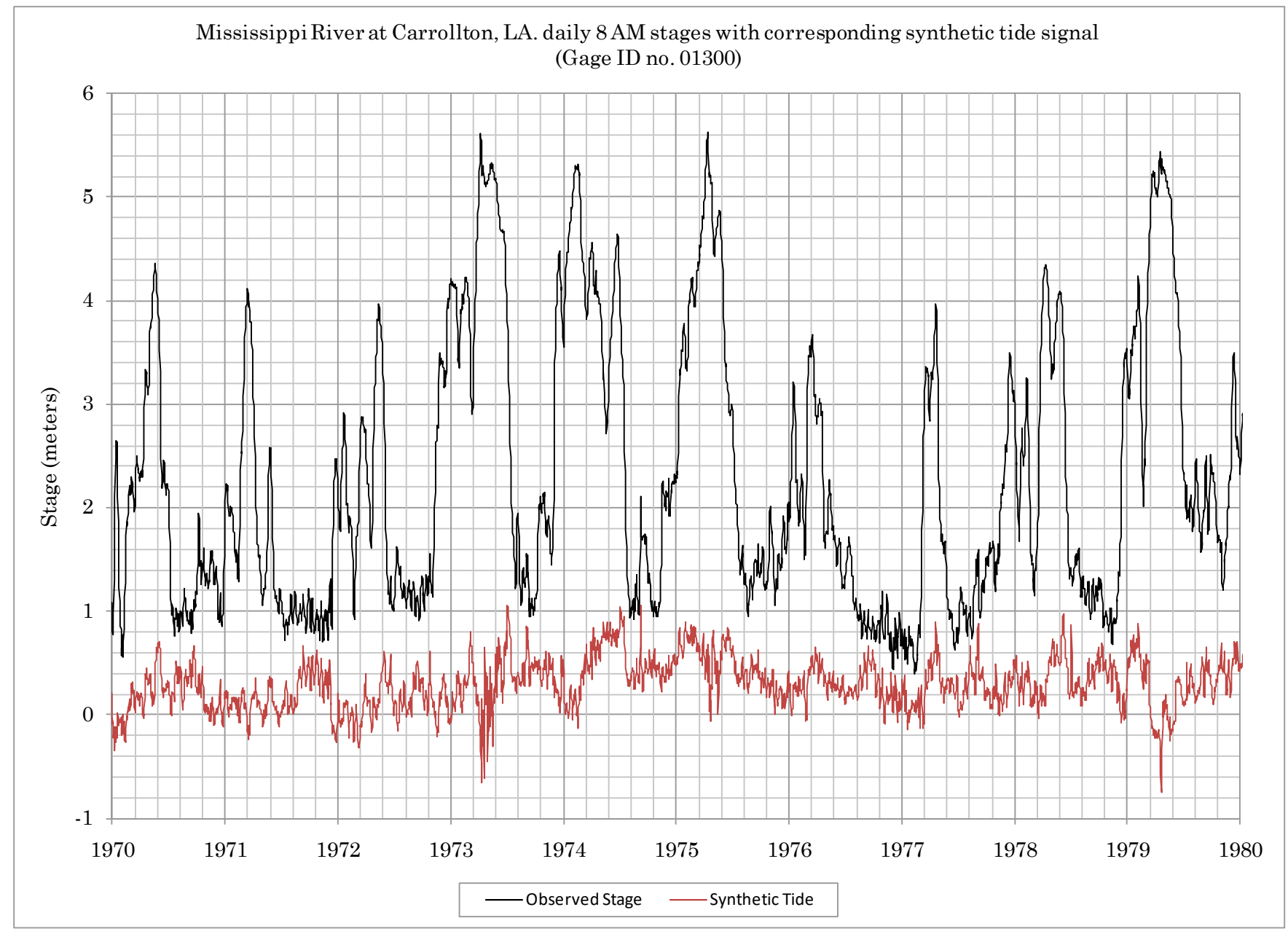




\section{Results}

The results of the linear trend analyses performed on the daily tide data recorded at 30 USACE gages are summarized in Table 1 and on Figures 8 and 9. Appendix A contains graphs of the daily tide data used in the analyses along with the linear trend lines developed for each gage site.

Table 1. Summary table of 2015 Updated Relative Sea Level Trends for USACE gages.

\begin{tabular}{|c|c|c|c|c|c|}
\hline Gage Name & $\begin{array}{l}\text { USACE } \\
\text { MVN Gage } \\
\text { ID Number }\end{array}$ & $\begin{array}{l}\text { Latitude and } \\
\text { Longitude }\end{array}$ & $\begin{array}{l}\text { Period of } \\
\text { Record } \\
\text { Analyzed }\end{array}$ & \begin{tabular}{|l|}
2010 Linear \\
Trend for Entire \\
Period of Record \\
(mm/year)
\end{tabular} & $\begin{array}{l}2015 \text { Linear } \\
\text { Trend for Entire } \\
\text { Period of Record } \\
(\mathrm{mm} / \text { year) }\end{array}$ \\
\hline \multirow{2}{*}{$\begin{array}{l}\text { Mississippi River at New } \\
\text { Orleans (Carrollton) }{ }^{* *}\end{array}$} & \multirow[t]{2}{*}{01300} & 29-56-05 & \multirow{2}{*}{$\begin{array}{l}\text { Jan } 1950- \\
\text { Dec } 2014\end{array}$} & \multirow{2}{*}{$18.6(9.2)$} & \multirow{2}{*}{$9.6(7.1)^{1}$} \\
\hline & & $90-08-10$ & & & \\
\hline \multirow{2}{*}{$\begin{array}{l}\text { Mississippi River at IHNC } \\
\text { Lock }^{* *}\end{array}$} & \multirow[t]{2}{*}{01340} & $29-51-91$ & \multirow{2}{*}{$\begin{array}{l}\text { Jan } 1945- \\
\text { Dec } 2014\end{array}$} & & \multirow{2}{*}{$8.18(6.80)$} \\
\hline & & $90-01-38$ & & & \\
\hline \multirow{2}{*}{$\begin{array}{l}\text { Mississippi River at West } \\
\text { Pointe a la Hache }{ }^{\star *}\end{array}$} & \multirow[t]{2}{*}{01400} & 29-34-16 & \multirow{2}{*}{$\begin{array}{l}\text { Jan } 1950- \\
\text { Dec } 2014\end{array}$} & \multirow{2}{*}{$12.6(13.1)$} & \multirow{2}{*}{$11.75(11.52)$} \\
\hline & & $89-47-49$ & & & \\
\hline \multirow[t]{2}{*}{ Mississippi River at Venice ${ }^{* *}$} & \multirow[t]{2}{*}{01480} & 29-16-33 & \multirow{2}{*}{$\begin{array}{l}\text { Jan } 1953- \\
\text { Aug } 2005\end{array}$} & \multirow{2}{*}{$21.8(23.0)$} & \multirow{2}{*}{$21.8(23.0)$} \\
\hline & & $89-21-10$ & & & \\
\hline \multirow[t]{2}{*}{ Southwest Pass at East Jetty } & \multirow[t]{2}{*}{01670} & $28-55-38$ & \multirow{2}{*}{$\begin{array}{l}\text { Jan } 1953- \\
\text { Dec } 2014\end{array}$} & \multirow{2}{*}{25.7} & \multirow{2}{*}{26.8} \\
\hline & & $89-29-12$ & & & \\
\hline \multirow[t]{2}{*}{ South Pass at Port Eads } & \multirow[t]{2}{*}{01850} & $29-00-53$ & \multirow{2}{*}{$\begin{array}{l}\text { Jan } 1953- \\
\text { Dec } 2004\end{array}$} & \multirow{2}{*}{25.5} & \multirow{2}{*}{25.5} \\
\hline & & $89-09-57$ & & & \\
\hline \multirow{2}{*}{$\begin{array}{l}\text { Avoca Island Cutoff South of } \\
\text { Morgan City }\end{array}$} & \multirow[t]{2}{*}{03820} & $29-32-18$ & \multirow{2}{*}{$\begin{array}{l}\text { Feb } 1956- \\
\text { Dec } 2014\end{array}$} & & \multirow{2}{*}{2.05} \\
\hline & & 91-14-44 & & & \\
\hline \multirow{2}{*}{$\begin{array}{l}\text { Catfish Point Control Structure } \\
\text { - North }\end{array}$} & \multirow[t]{2}{*}{70675} & 29-51-48 & \multirow{2}{*}{$\begin{array}{l}\text { Jan } 1955- \\
\text { Dec } 2014\end{array}$} & & \multirow[b]{2}{*}{1.61} \\
\hline & & $92-50-54$ & & & \\
\hline
\end{tabular}

\footnotetext{
1 The change from the original Tidegage Atlas to this update in the apparent rate of sea level change at the Carrollton gage, based on raw stage data, is large enough (18.6 mm/yr to 9.6) that it caught the attention of several reviewers and deserves a special note. Note that this change is in the raw data rather than the synthetic data with river discharge influences removed. The change in the synthetic data (from $9.2 \mathrm{~mm} / \mathrm{yr}$ to 7.1 ) is also substantial in a relative sense but is comparable in absolute terms to changes observed at other gages. Because this gage is located on the Mississippi River, the raw data are subject to influence from river discharge, so it does not reflect sea level change alone and should not be used for most purposes. District staff investigated this dataset closely to ensure that no datum shifts or other errors were missed in the analysis, finding none. It appears that the apparent fall in stage is related to relatively lower river discharge in the years 2011-2015 which included periods of severe drought in 2012 and 2013 (though it also included floods in 2011 and 2015). This, combined with random variations in the data, is the most likely explanation for the apparent slowdown in subsidence being greater at this gage than other gages nearby.
} 


\begin{tabular}{|c|c|c|c|c|c|}
\hline Gage Name & $\begin{array}{l}\text { USACE } \\
\text { MVN Gage } \\
\text { ID Number }\end{array}$ & $\begin{array}{l}\text { Latitude and } \\
\text { Longitude }\end{array}$ & $\begin{array}{l}\text { Period of } \\
\text { Record } \\
\text { Analyzed }\end{array}$ & $\begin{array}{l}2010 \text { Linear } \\
\text { Trend for Entire } \\
\text { Period of Record } \\
\text { (mm/year) }\end{array}$ & $\begin{array}{l}2015 \text { Linear } \\
\text { Trend for Entire } \\
\text { Period of Record } \\
\text { (mm/year) }^{*}\end{array}$ \\
\hline \multirow{2}{*}{$\begin{array}{l}\text { Catfish Point Control Structure } \\
\text { - South }\end{array}$} & \multirow[t]{2}{*}{70750} & $29-51-47$ & \multirow{2}{*}{$\begin{array}{l}\text { Jan } 1955- \\
\text { Dec } 2014\end{array}$} & & \multirow{2}{*}{3.83} \\
\hline & & $92-50-56$ & & & \\
\hline \multirow{2}{*}{$\begin{array}{l}\text { Calcasieu River and Pass at } \\
\text { Lake Charles }\end{array}$} & \multirow[t]{2}{*}{73550} & 30-13-05 & \multirow{2}{*}{ Jan 1950} & \multirow{2}{*}{6.1} & \multirow{2}{*}{6.1} \\
\hline & & $93-15-12$ & & & \\
\hline \multirow{2}{*}{$\begin{array}{l}\text { Calcasieu River and Pass near } \\
\text { Cameron }\end{array}$} & \multirow[t]{2}{*}{73650} & $29-46-30$ & \multirow{2}{*}{\begin{tabular}{|l} 
Jan $1950-$ \\
Aug 2005
\end{tabular}} & \multirow{2}{*}{3.9} & \multirow{2}{*}{3.9} \\
\hline & & $93-20-46$ & & & \\
\hline \multirow[t]{2}{*}{ IHNC at New Orleans } & \multirow[t]{2}{*}{76160} & $29-57-59$ & \multirow{2}{*}{$\begin{array}{l}\text { Jan } 1945- \\
\text { Dec } 2014\end{array}$} & & \multirow{2}{*}{10.47} \\
\hline & & $90-01-36$ & & & \\
\hline \multirow{2}{*}{$\begin{array}{l}\text { Bayou Petit Caillou at } \\
\text { Cocodrie }\end{array}$} & \multirow[t]{2}{*}{76305} & $29-14-43$ & \multirow{2}{*}{$\begin{array}{l}\text { Mar } 1969- \\
\text { Dec } 2014\end{array}$} & \multirow{2}{*}{6.4} & \multirow{2}{*}{6.3} \\
\hline & & $90-39-48$ & & & \\
\hline \multirow[t]{2}{*}{ GIWW at Houma } & \multirow[t]{2}{*}{76320} & $29-35-53$ & \multirow{2}{*}{$\begin{array}{l}\text { Jan } 1959- \\
\text { Nov } 2008\end{array}$} & & \multirow{2}{*}{20.6} \\
\hline & & $90-42-35$ & & & \\
\hline \multirow[t]{2}{*}{ Bayou Boeuf Lock - East } & \multirow[t]{2}{*}{76360} & $29-40-59$ & Jan 1955 - & & \\
\hline & & 91-10-19 & Dec 2014 & & 6.99 \\
\hline Freshwater Canal at & 76593 & 29-33-09 & Jul 1968 - & & \\
\hline $\begin{array}{l}\text { Freshwater Bayou Lock } \\
\text { (South) }\end{array}$ & & 92-18-21 & Oct 2012 & 5.4 & 3.6 \\
\hline Schooner Bayou Control & 76600 & 29-45-27 & Jan 1955 - & & 506 \\
\hline & & $92-15-49$ & & & 0.90 \\
\hline Schooner Bayou Control & 76680 & $29-45-28$ & Jan 1961 - & & 175 \\
\hline & & $92-15-51$ & Dec 2014 & & 4.15 \\
\hline IWW at Leland Bowman Lock - & 76720 & $29-47-6$ & Jan 1959 - & & 542 \\
\hline & & $92-12-17$ & Dec 2014 & & 0.42 \\
\hline IWW at Leland Bowman Lock - & 76800 & $29-47-10$ & Jan 1951 - & & רחת \\
\hline & & $92-12-29$ & July 2013 & & 3.02 \\
\hline Intracoastal Waterway at & 76960 & $30-05-19$ & Jan 1951 - & 52 & 118 \\
\hline Calcasieu Lock (West) & & 93-17-40 & Aug 2014 & 5.2 & 4.8 \\
\hline Bayou Lafourche at Leeville & 82350 & 29-14-52 & Nov $1955-$ & 108 & 108 \\
\hline & & $90-12-32$ & Apr 2000 & 10.0 & 10.0 \\
\hline Bayou Barataria at Barataria & 82750 & 29-44-29 & Jan 1950 - & 7 & \\
\hline & & $90-07-56$ & Nov 1992 & 7 & 7 \\
\hline Lake Pontchartrain at Frenier & 85550 & $30-06-22$ & Jan 1950 - & 01 & 01 \\
\hline & & $90-25-17$ & 2002 & 8.4 & 8.4 \\
\hline Lake Pontchartrain at & 85575 & $30-21-31$ & Aug 1957 - & & \\
\hline Mandeville & & 90-05-45 & Jul 2002 & 6.6 & 0.6 \\
\hline
\end{tabular}




\begin{tabular}{|c|c|c|c|c|c|}
\hline Gage Name & $\begin{array}{l}\text { USACE } \\
\text { MVN Gage } \\
\text { ID Number }\end{array}$ & $\begin{array}{l}\text { Latitude and } \\
\text { Longitude }\end{array}$ & $\begin{array}{l}\text { Period of } \\
\text { Record } \\
\text { Analyzed }\end{array}$ & $\begin{array}{l}2010 \text { Linear } \\
\text { Trend for Entire } \\
\text { Period of Record } \\
\text { (mm/year) }\end{array}$ & $\begin{array}{l}2015 \text { Linear } \\
\text { Trend for Entire } \\
\text { Period of Record } \\
\text { (mm/year) }^{*}\end{array}$ \\
\hline \multirow{2}{*}{$\begin{array}{l}\text { Lake Pontchartrain at West } \\
\text { End }\end{array}$} & \multirow[t]{2}{*}{85625} & 30-01-18 & \multirow{2}{*}{$\begin{array}{l}\text { Jan } 1950- \\
\text { Dec } 2014\end{array}$} & \multirow{2}{*}{9.1} & \multirow{2}{*}{8.81} \\
\hline & & $90-06-57$ & & & \\
\hline \multirow{2}{*}{$\begin{array}{l}\text { Rigolets near Lake } \\
\text { Pontchartrain }\end{array}$} & \multirow[t]{2}{*}{85700} & $30-10-02$ & \multirow{2}{*}{$\begin{array}{l}\text { Jan } 1950- \\
\text { Aug } 2001\end{array}$} & \multirow{2}{*}{4.7} & \multirow{2}{*}{4.7} \\
\hline & & 89-44-13 & & & \\
\hline \multirow{2}{*}{$\begin{array}{l}\text { Bayou Terre Aux Boeufs at } \\
\text { Delacroix }\end{array}$} & \multirow[t]{2}{*}{85780} & $29-45-50$ & \multirow{2}{*}{$\begin{array}{l}\text { May } 1975- \\
\text { Aug } 2005\end{array}$} & \multirow{2}{*}{6.1} & \multirow{2}{*}{6.1} \\
\hline & & $89-47-32$ & & & \\
\hline \multirow{2}{*}{$\begin{array}{l}\text { Mississippi River Gulf Outlet } \\
\text { at Shell Beach }\end{array}$} & \multirow[t]{2}{*}{85800} & 29-51-00 & \multirow{2}{*}{$\begin{array}{l}\text { Jun } 1961 \text { - } \\
\text { Dec } 2002\end{array}$} & \multirow{2}{*}{10.2} & \multirow{2}{*}{10.2} \\
\hline & & 89-41-00 & & & \\
\hline \multirow{2}{*}{$\begin{array}{l}\text { East Cote Blanche Bay at } \\
\text { Luke's Landing }\end{array}$} & \multirow[t]{2}{*}{88800} & $29-35-48$ & \multirow{2}{*}{$\begin{array}{l}\text { Feb } 1957- \\
\text { Oct } 2002\end{array}$} & \multirow{2}{*}{13.3} & \multirow{2}{*}{13.3} \\
\hline & & $91-32-35$ & & & \\
\hline
\end{tabular}

* Gages without a 2010 Linear Trend were added to the atlas during the 2015 update.

** The Mississippi River stage records for the Carrollton, West Pointe a la Hache, Venice, and IHNC Lock gages were analyzed to account for Mississippi River discharge stage influences. Estimates of the relative sea level rise using only the extracted tidal portion of the records are shown in parentheses.

Figure 8. Locations of USACE gages analyzed for relative sea level trends in Southwest Louisiana.

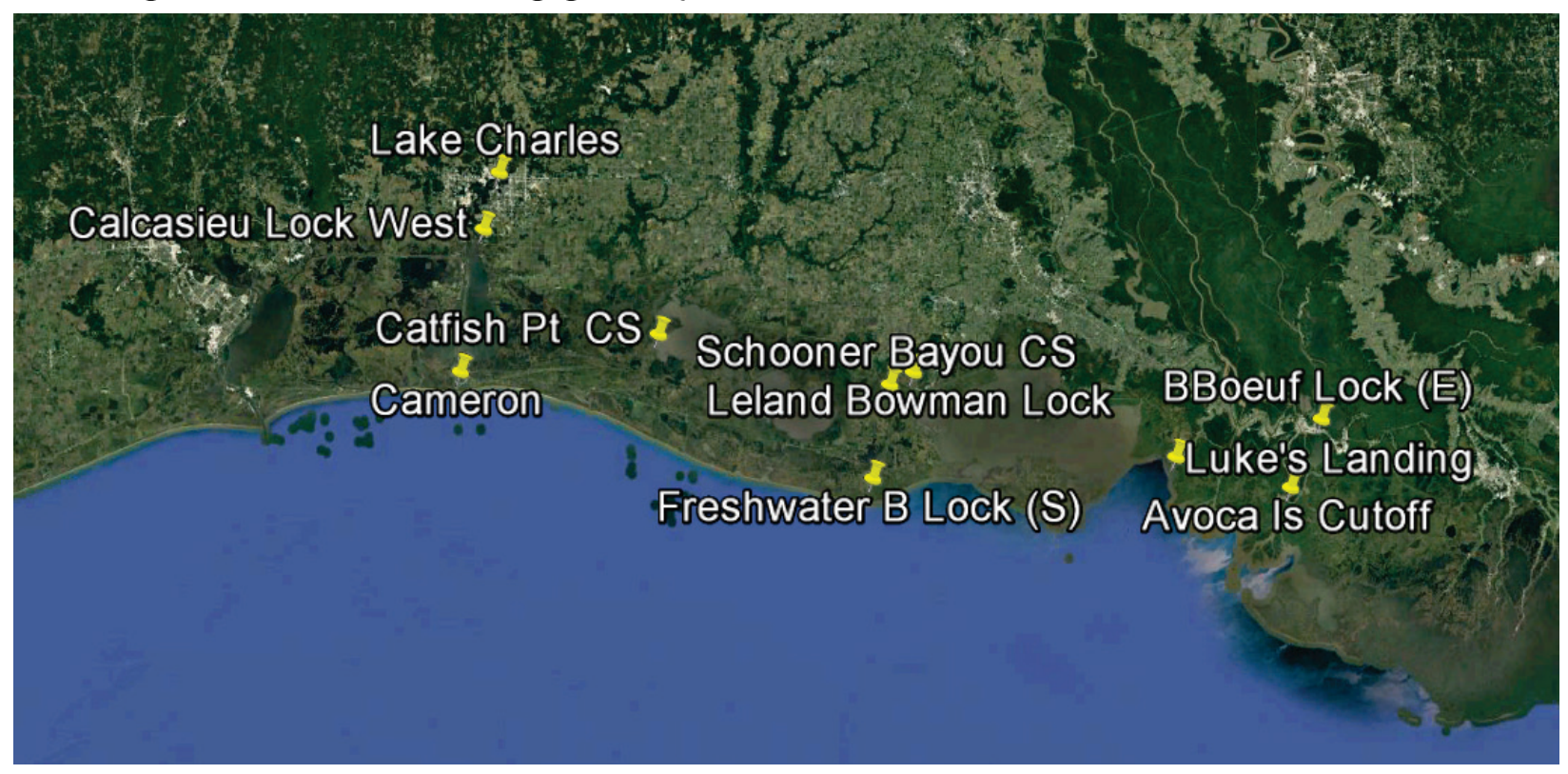


Figure 9. Locations of USACE gages analyzed for relative sea level trends in Southeast Louisiana.

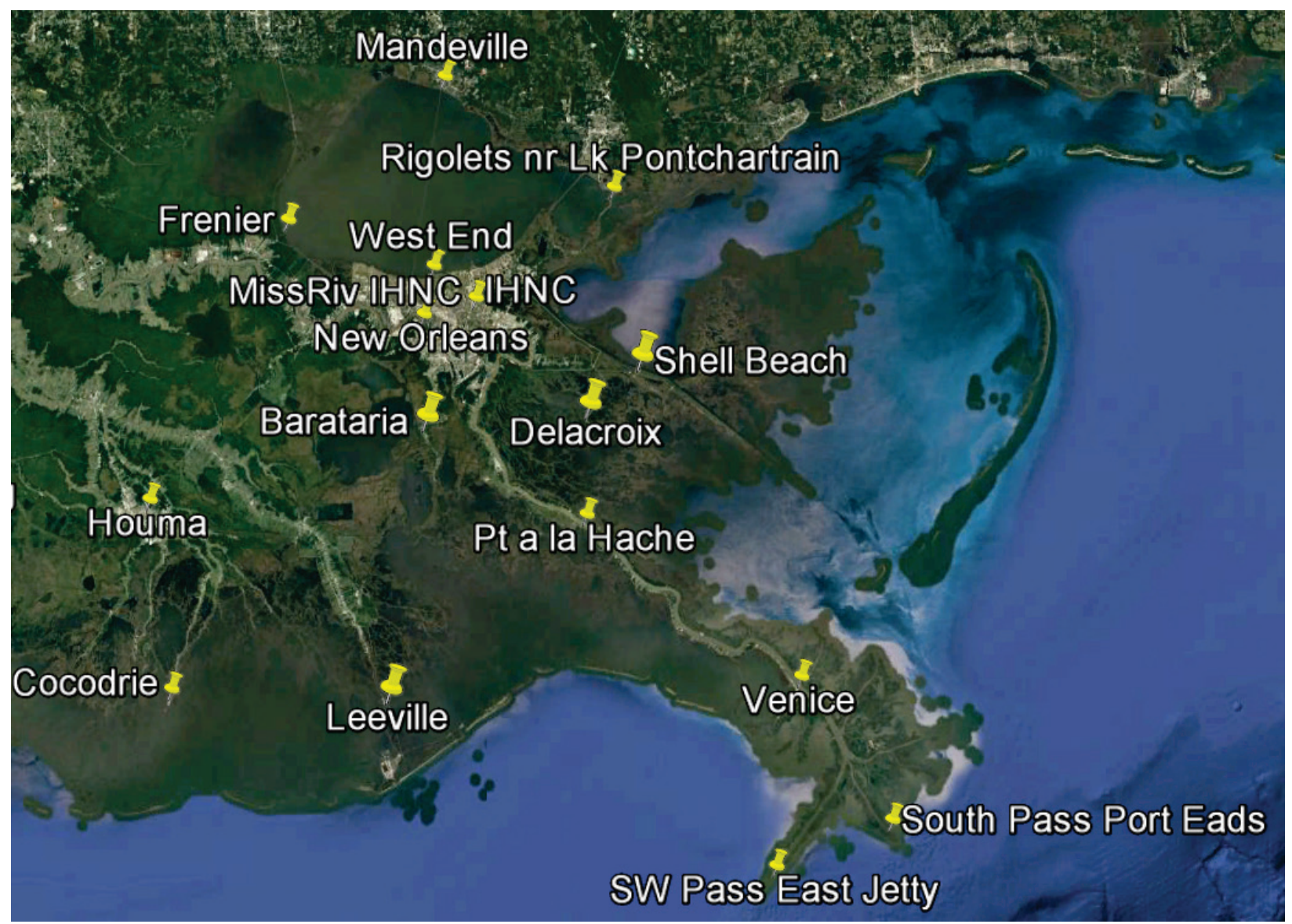




\section{Conclusion}

Historic daily tide measurements of USACE gages have been analyzed to determine relative sea level trends that are representative of the gage sites. These data are provided to supplement relative sea level rates provided by other sources (http://tidesandcurrents.noaa.gov/) and may be used to assist in the estimation of the components of relative sea level rise (eustatic and isostatic) to conduct analyses and future projections of sea level trends for project planning purposes. 


\section{References}

Gonzalez, J. L., and T. E. Tornqvist. 2006. "Coastal Louisiana in Crisis: Subsidence or Sea Level Rise?” Eos, Transactions, American Geophysical Union 87(45).

Intergovernmental Panel on Climate Change. 2007. IPCC Fourth Assessment Report: Climate Change 2007 (AR4). http://www.ipcc.ch/index.htm.

National Research Council. 1987. Responding to Changes in Sea Level: Engineering Implications. Washington, DC: National Academy Press.

Thieler, E. R., and E. S. Hammar-Klose. 200o. National Assessment of Coastal Vulnerability to Sea-Level Rise; Preliminary Results for the U.S. Gulf of Mexico Coast. U.S. Geological Survey Open-File Report No. 00-179. 2000.

U.S. Army Corps of Engineers (USACE). 2013. Incorporating Sea Level Change in Civil Works Programs. ER 1100-2-8162. Washington, DC. 


\section{Appendix: USACE Gages Daily Stage Graphs and Linear Trends}

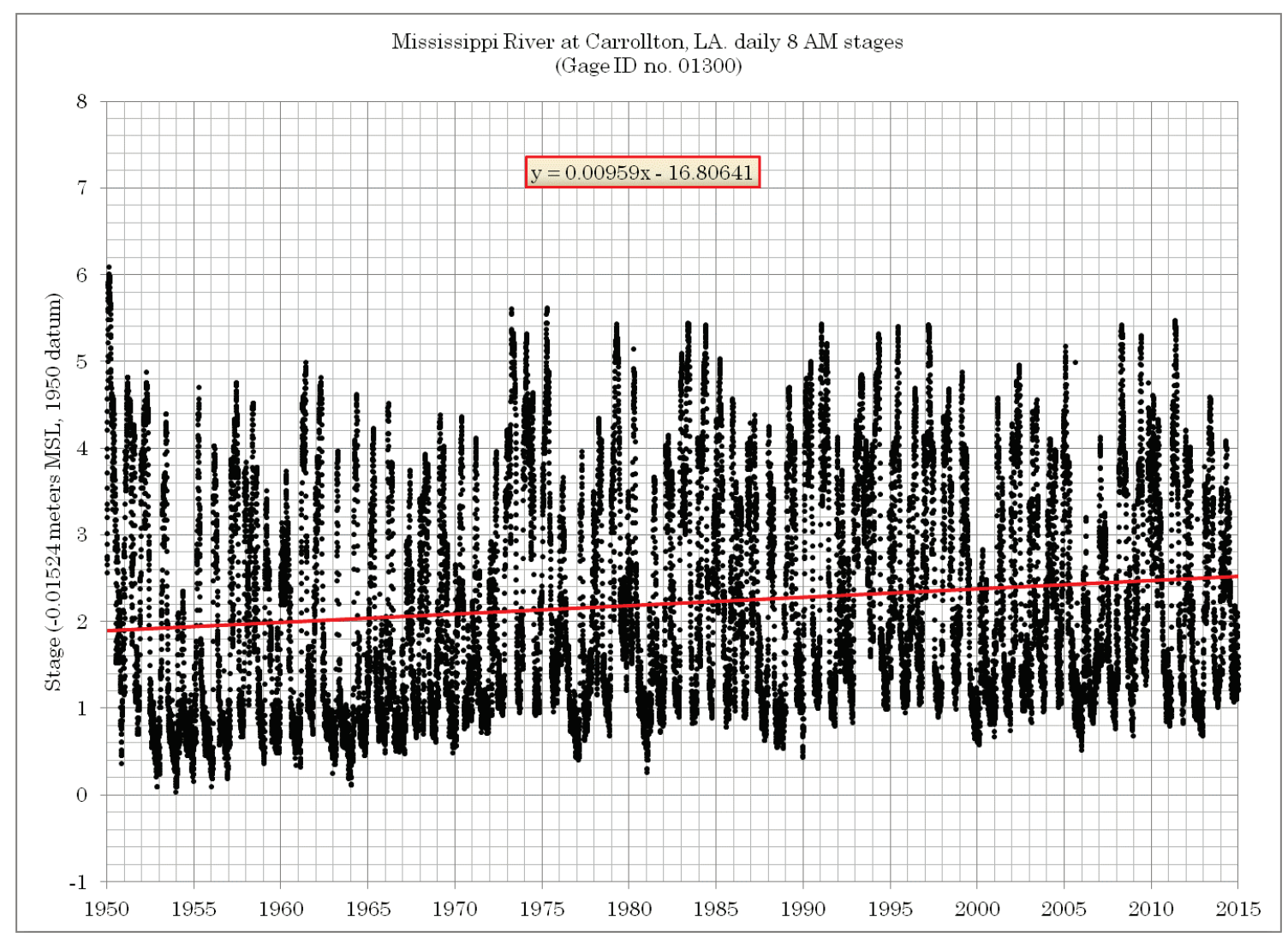



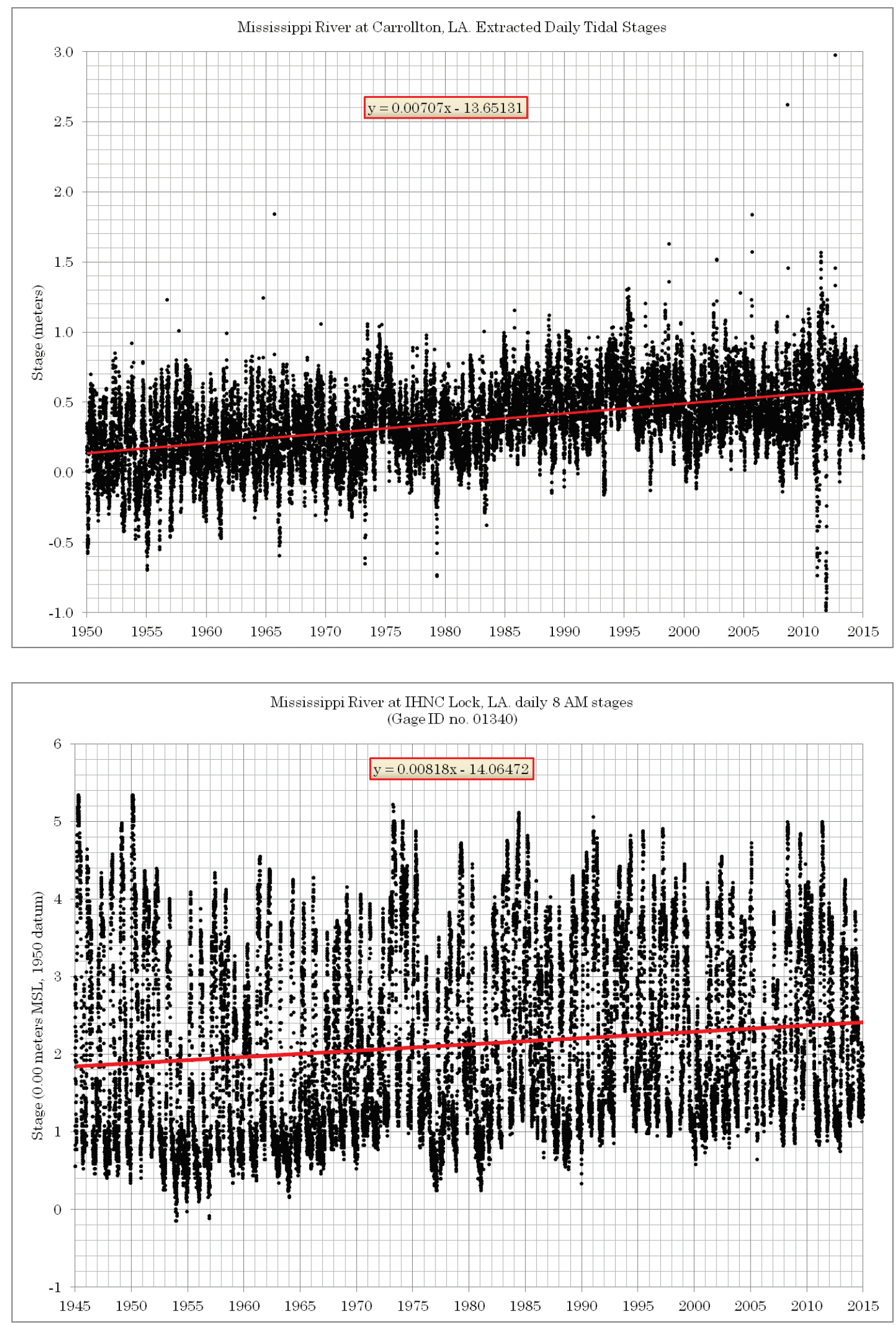

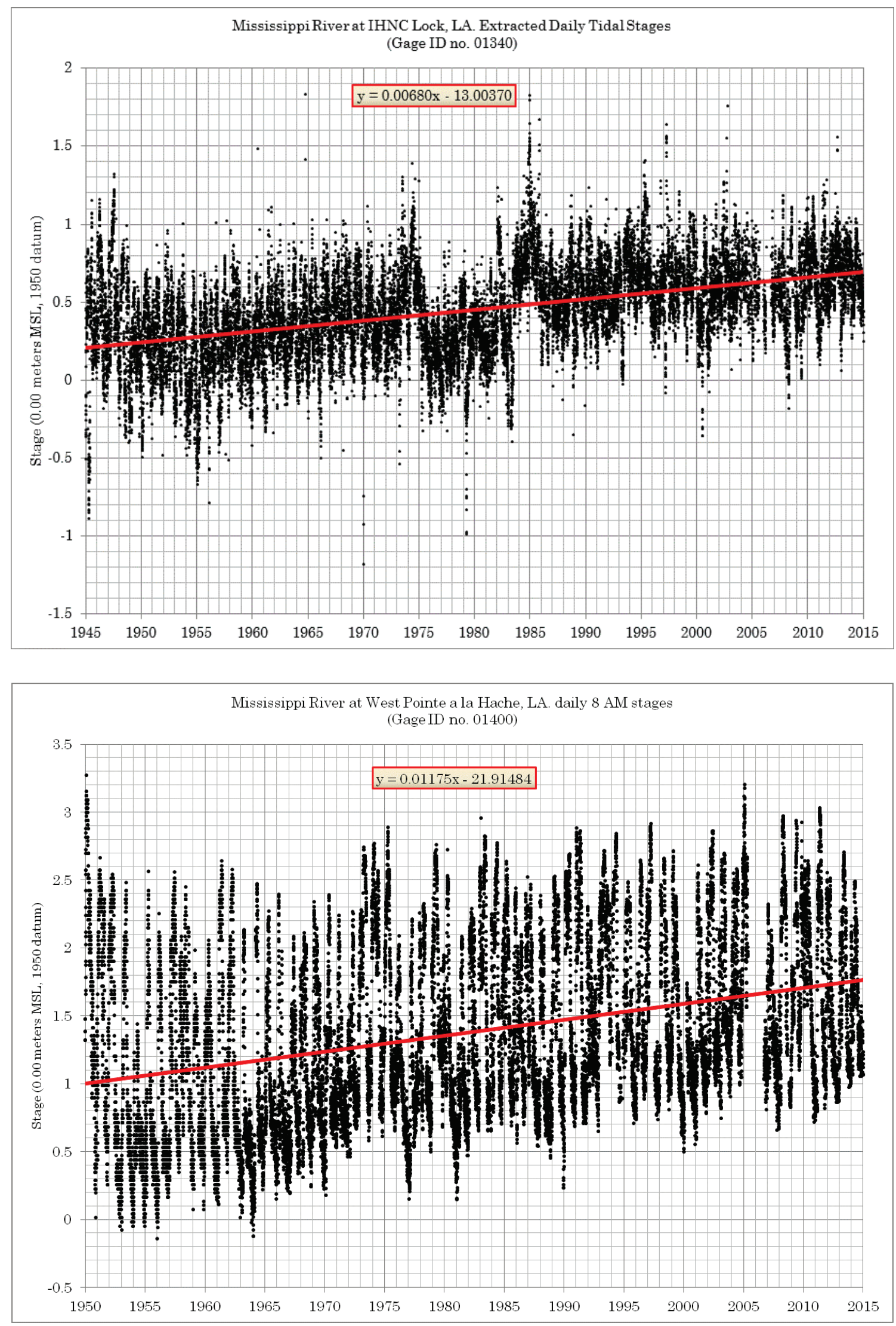

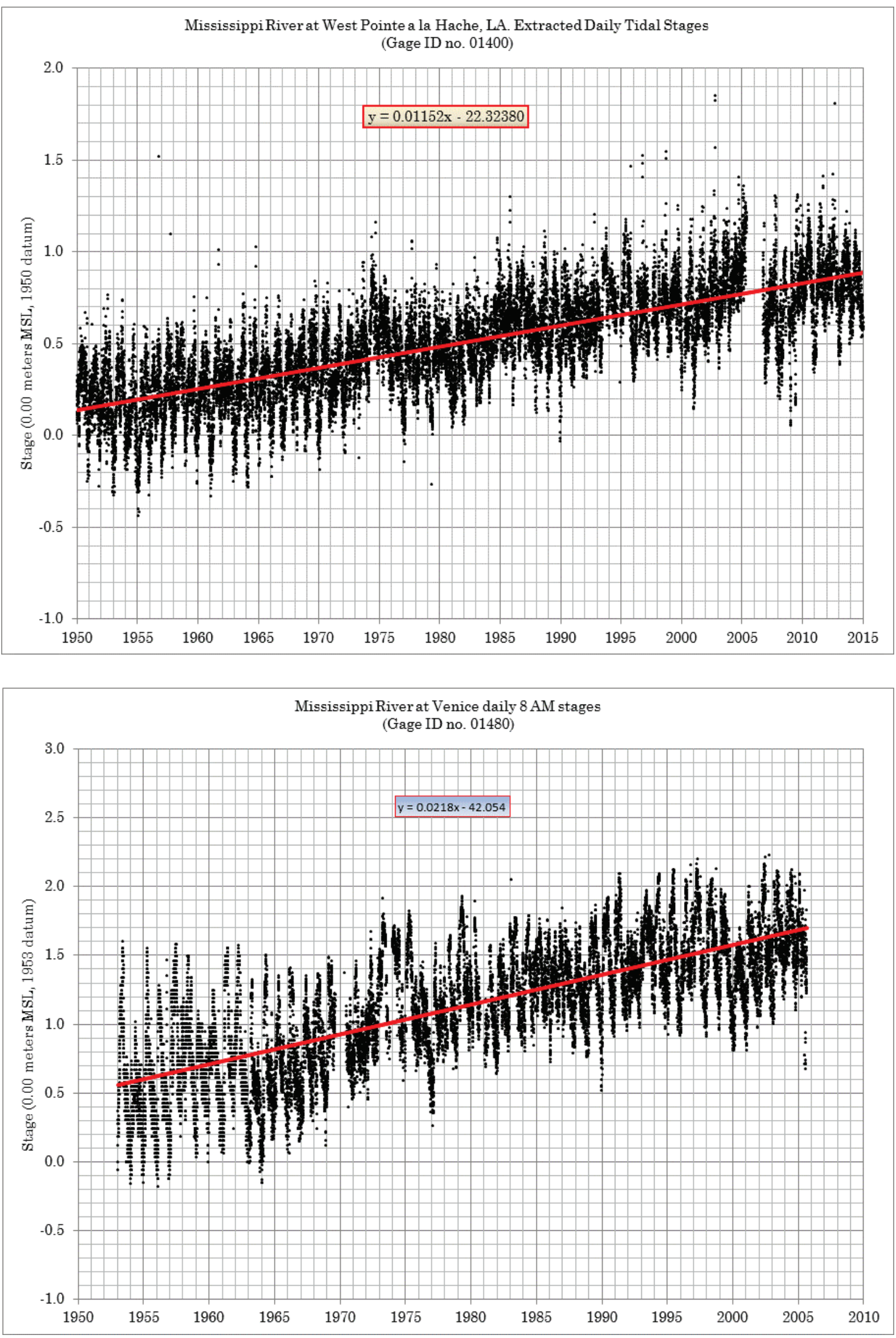

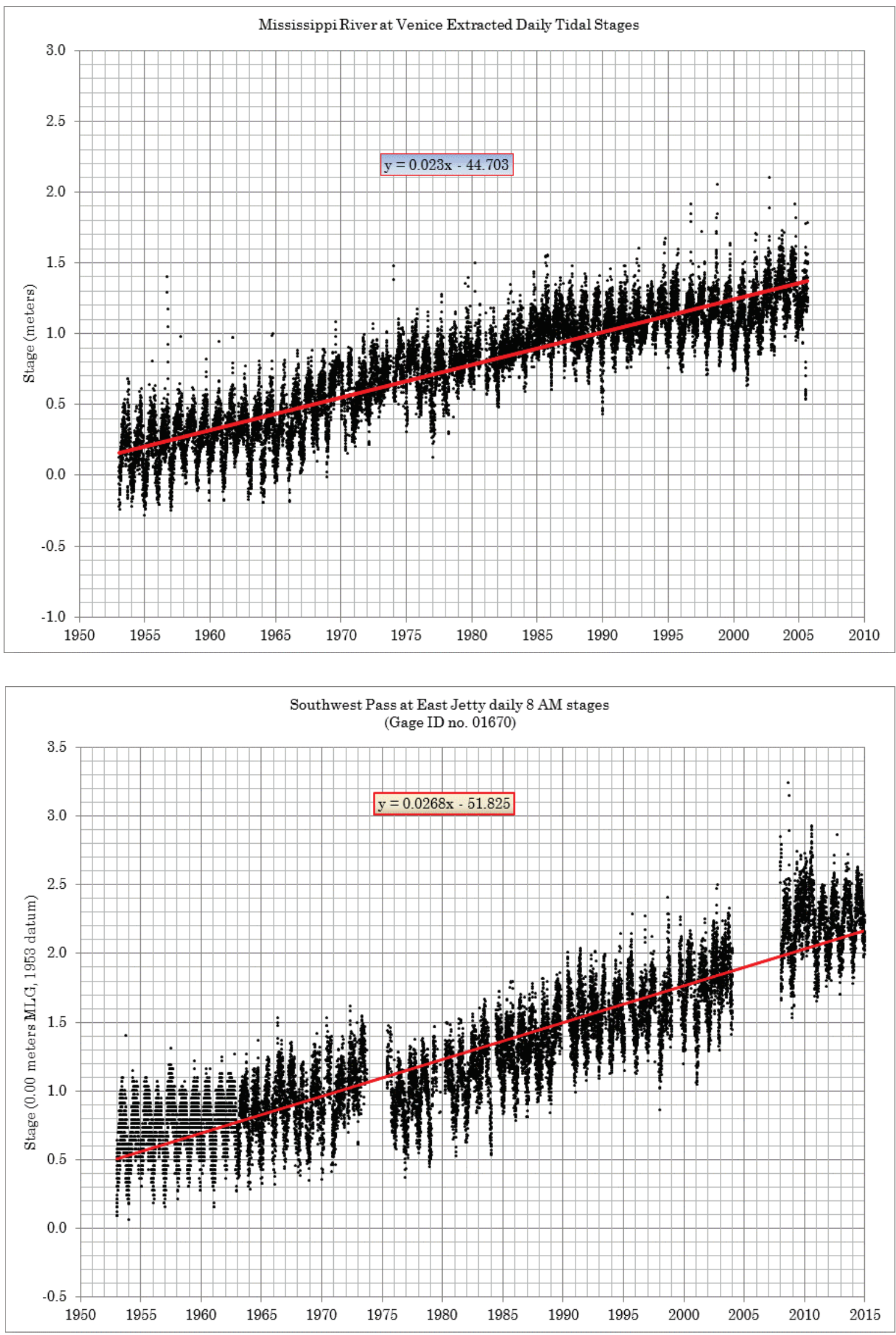

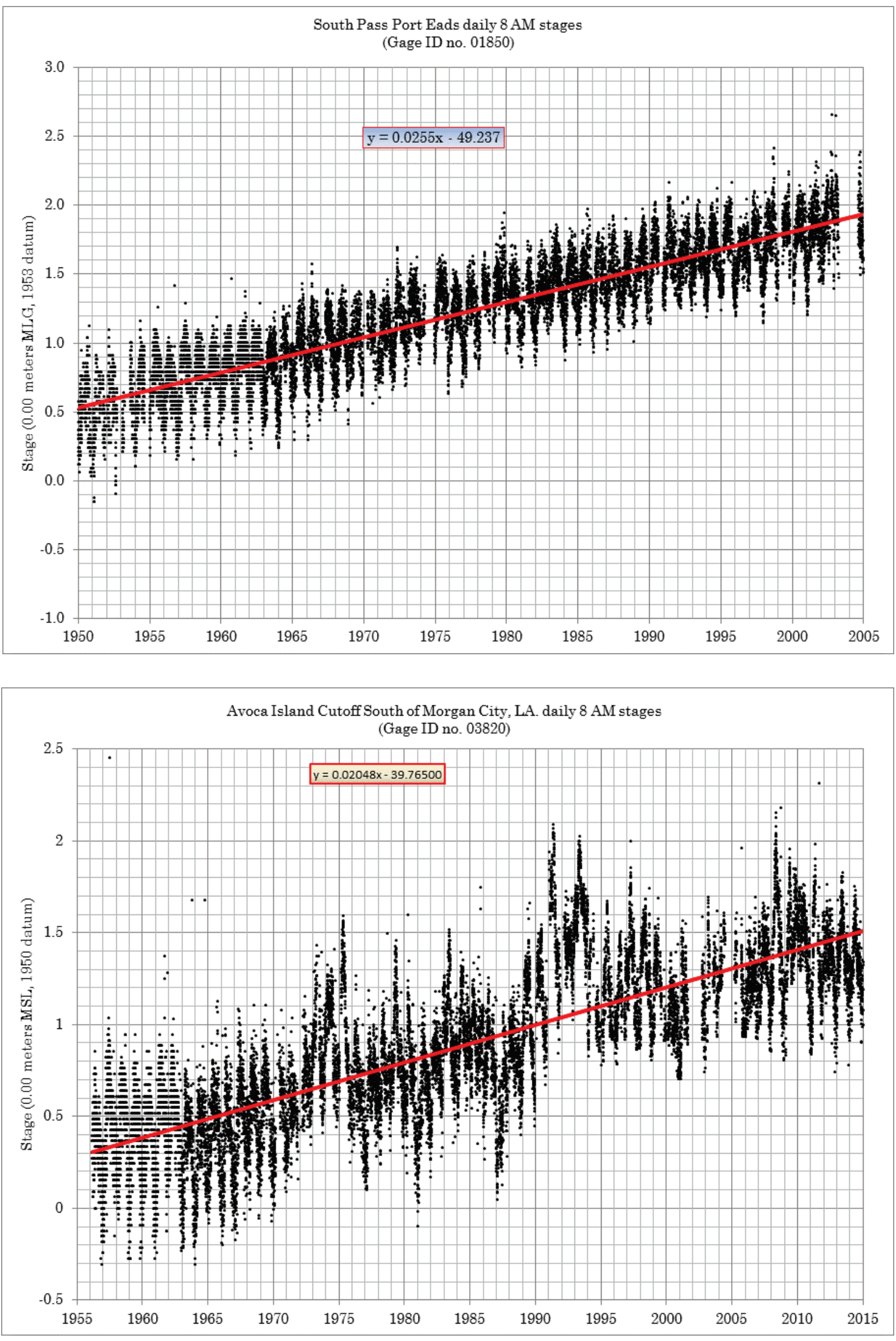

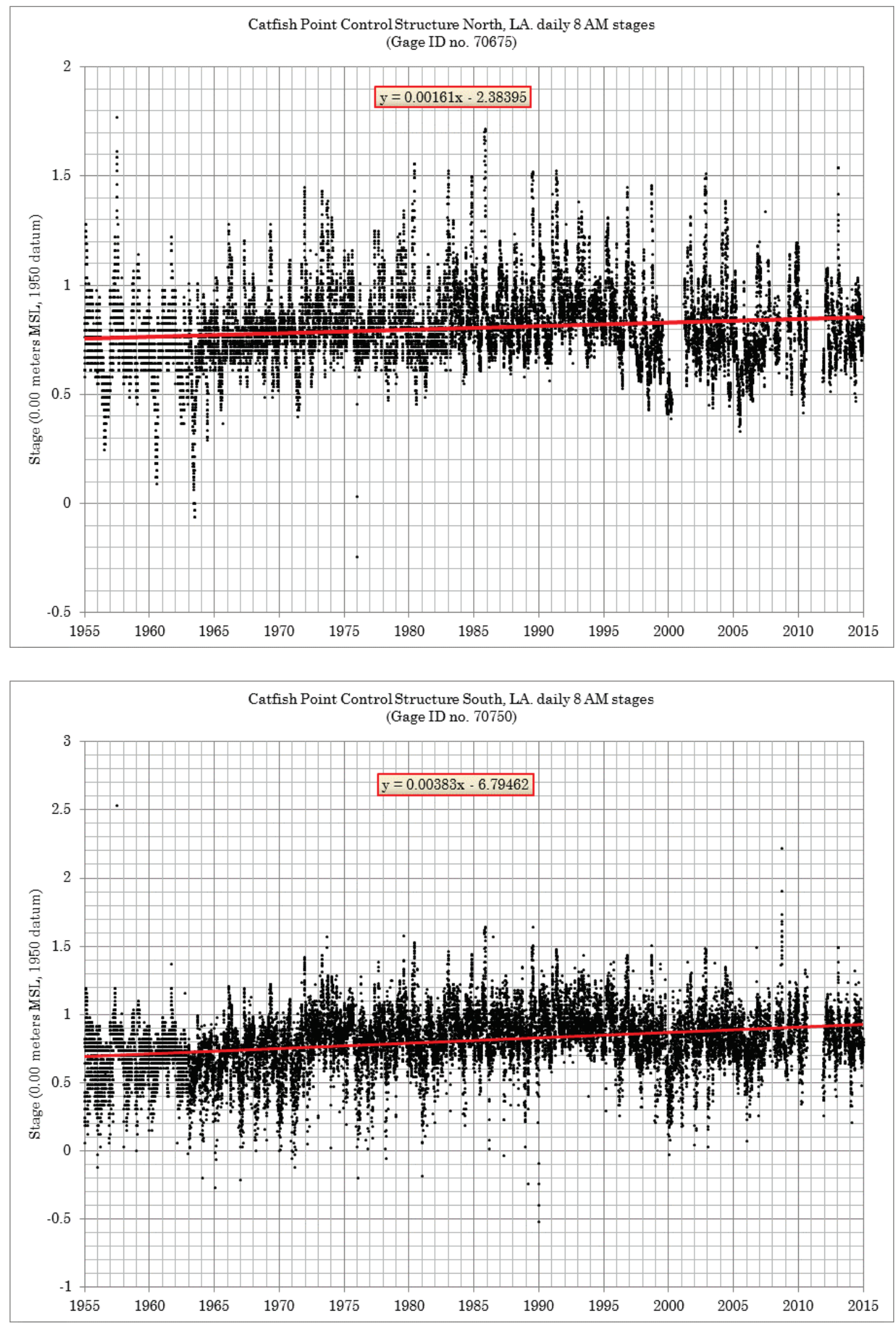

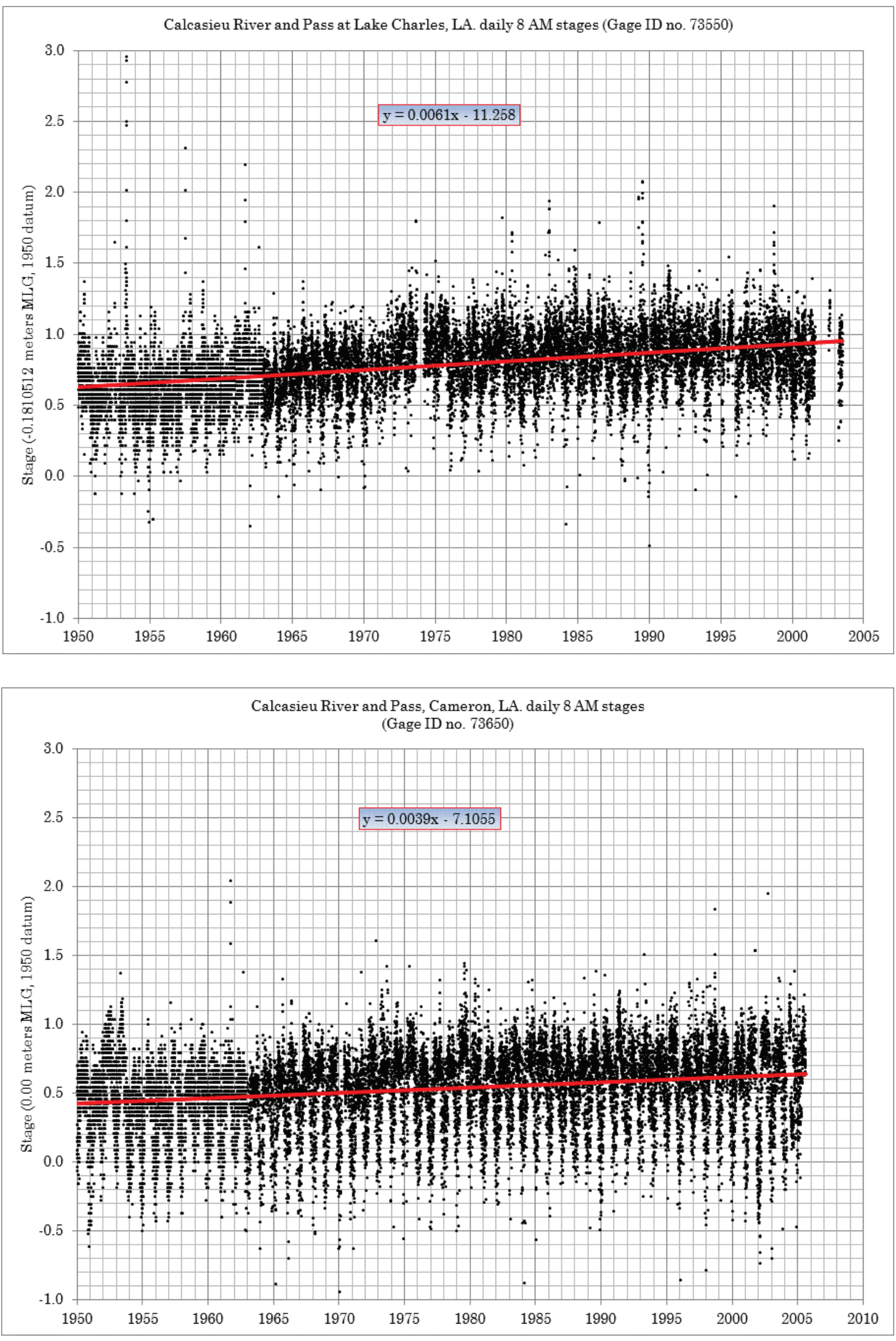

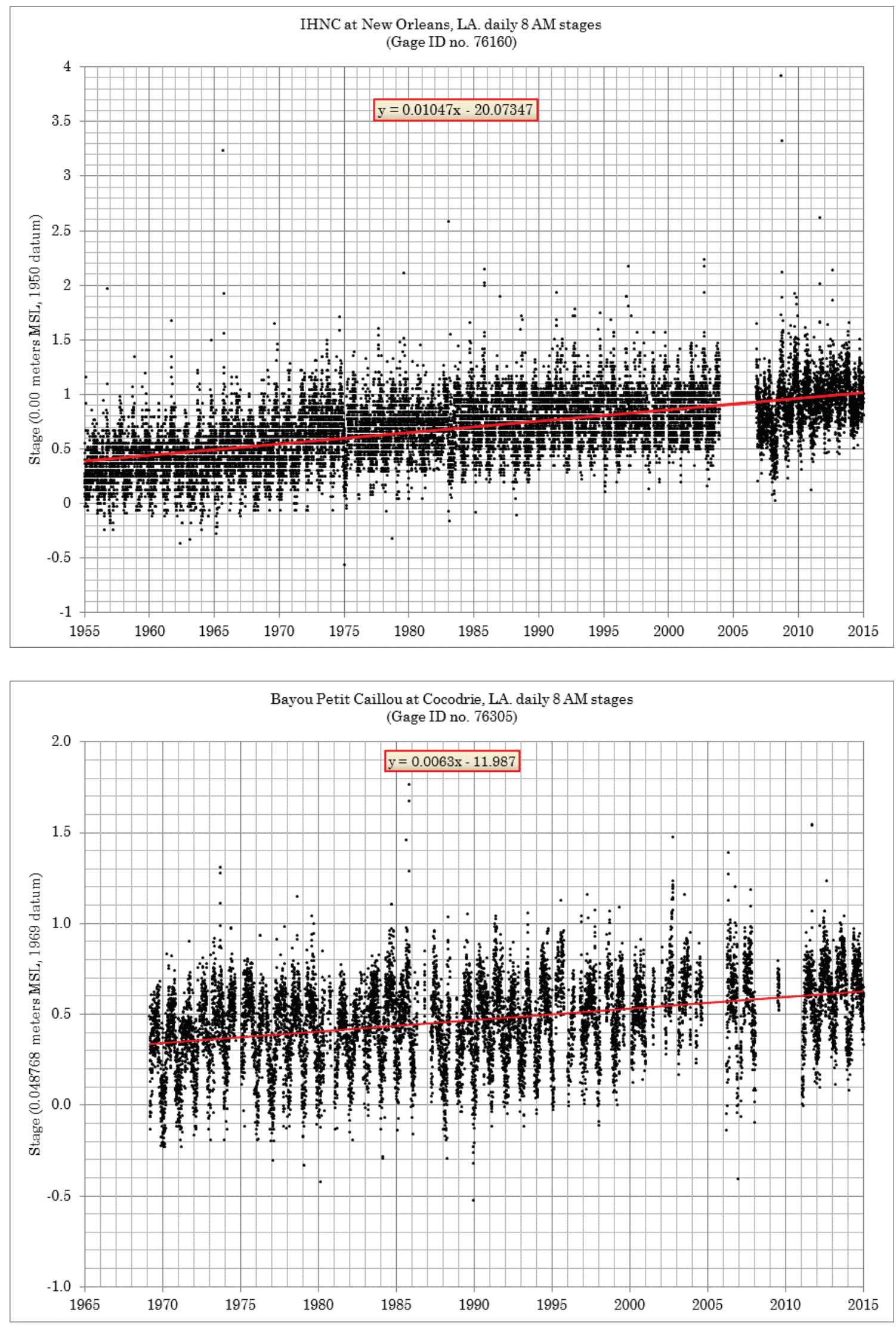

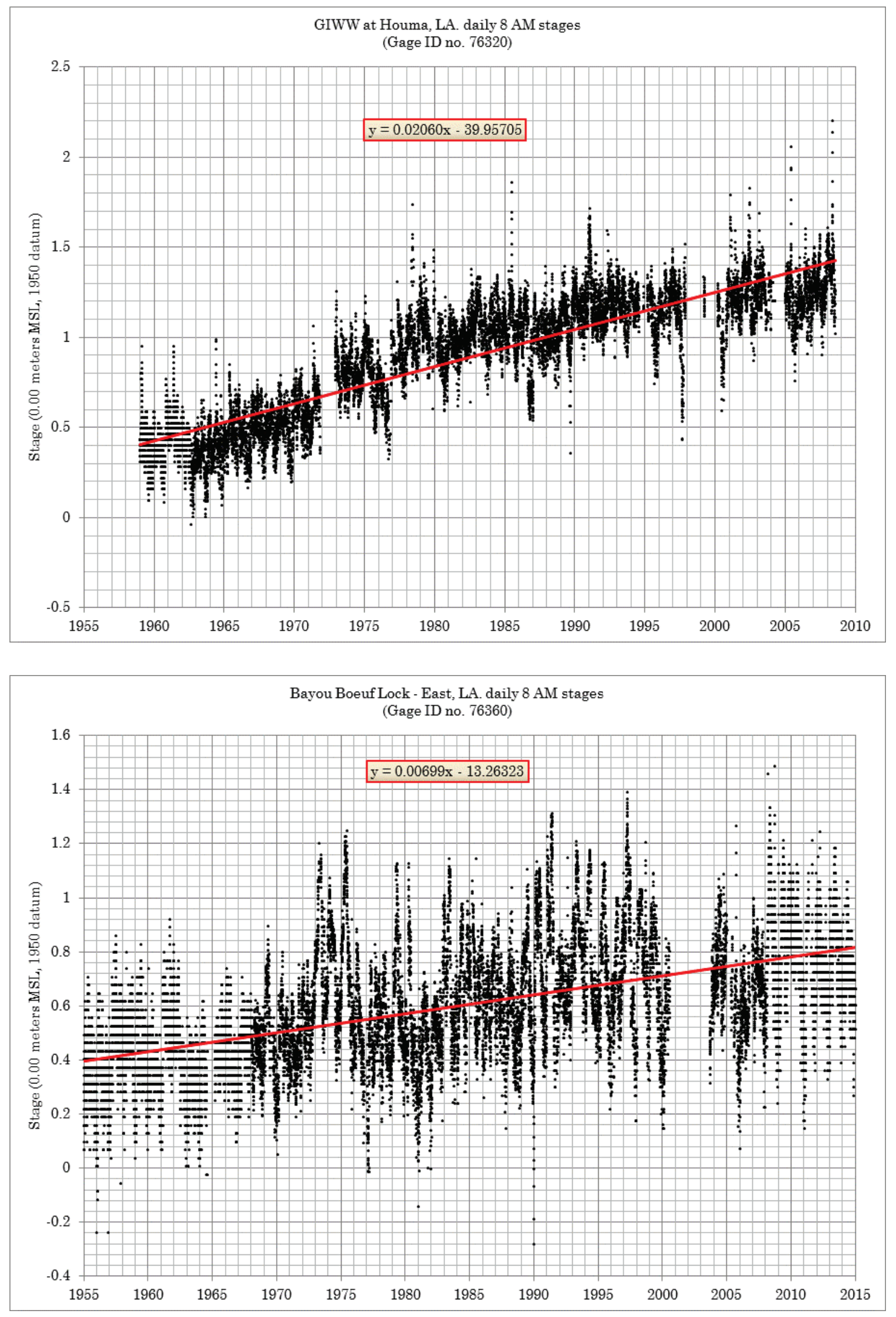

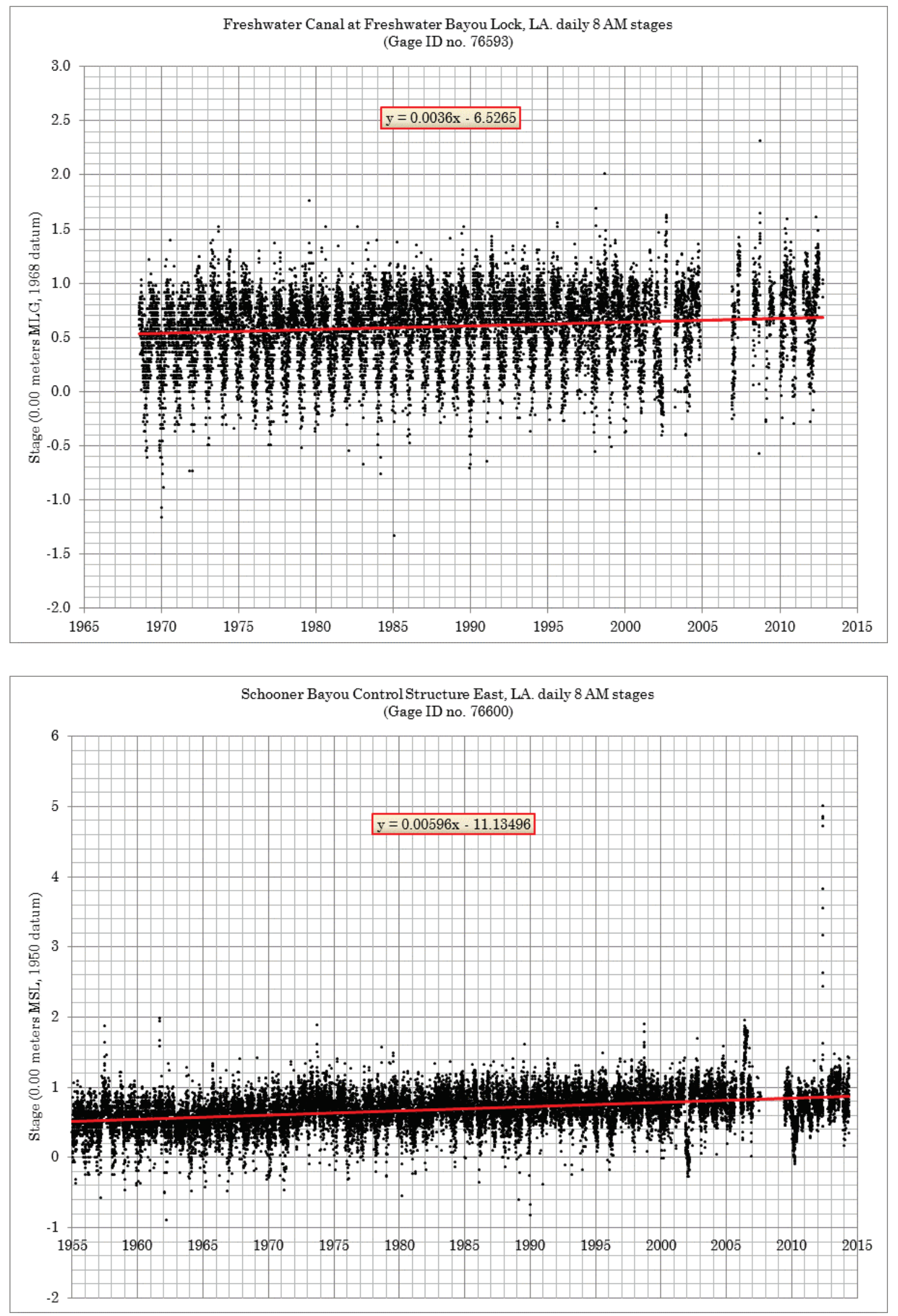

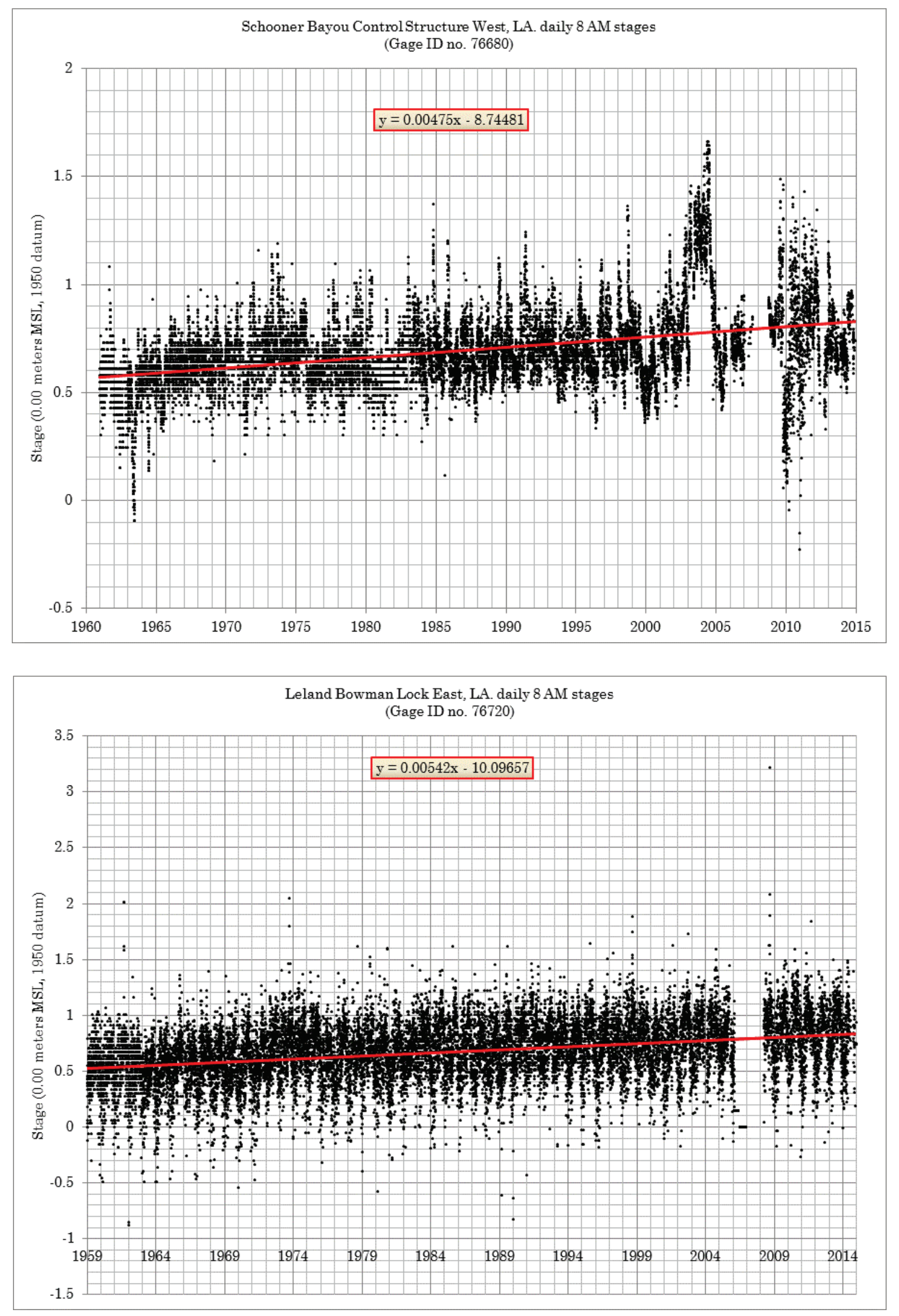

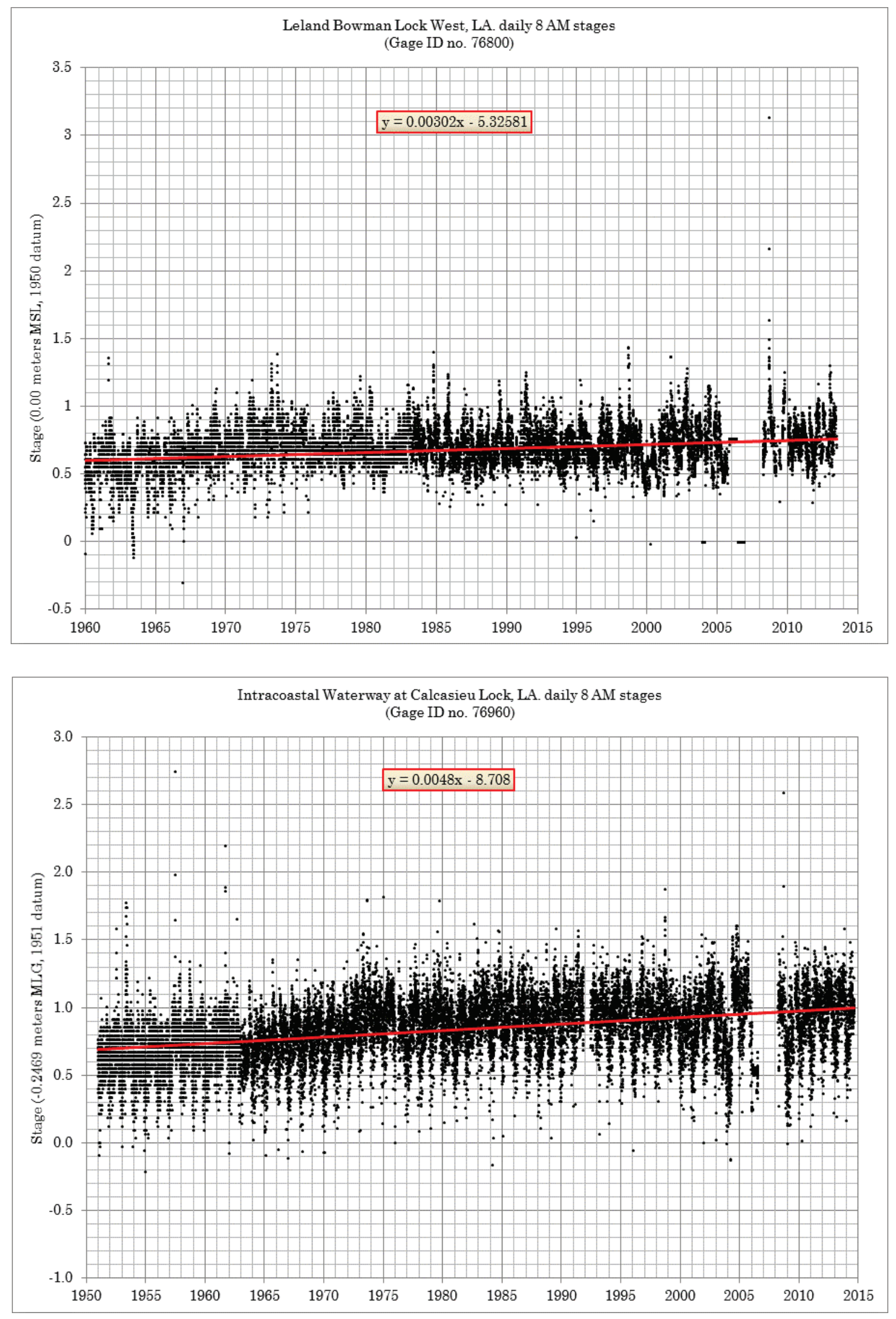

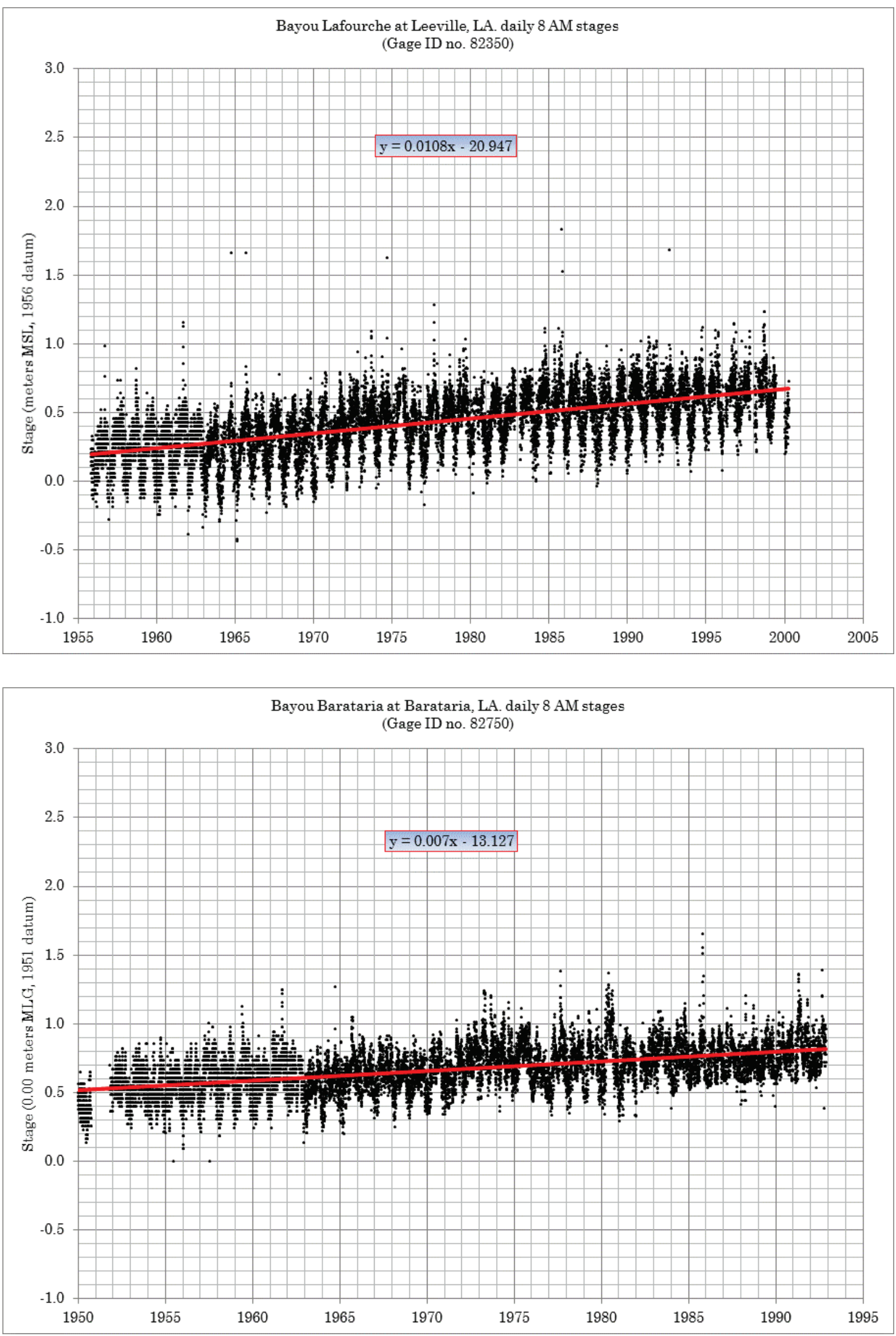

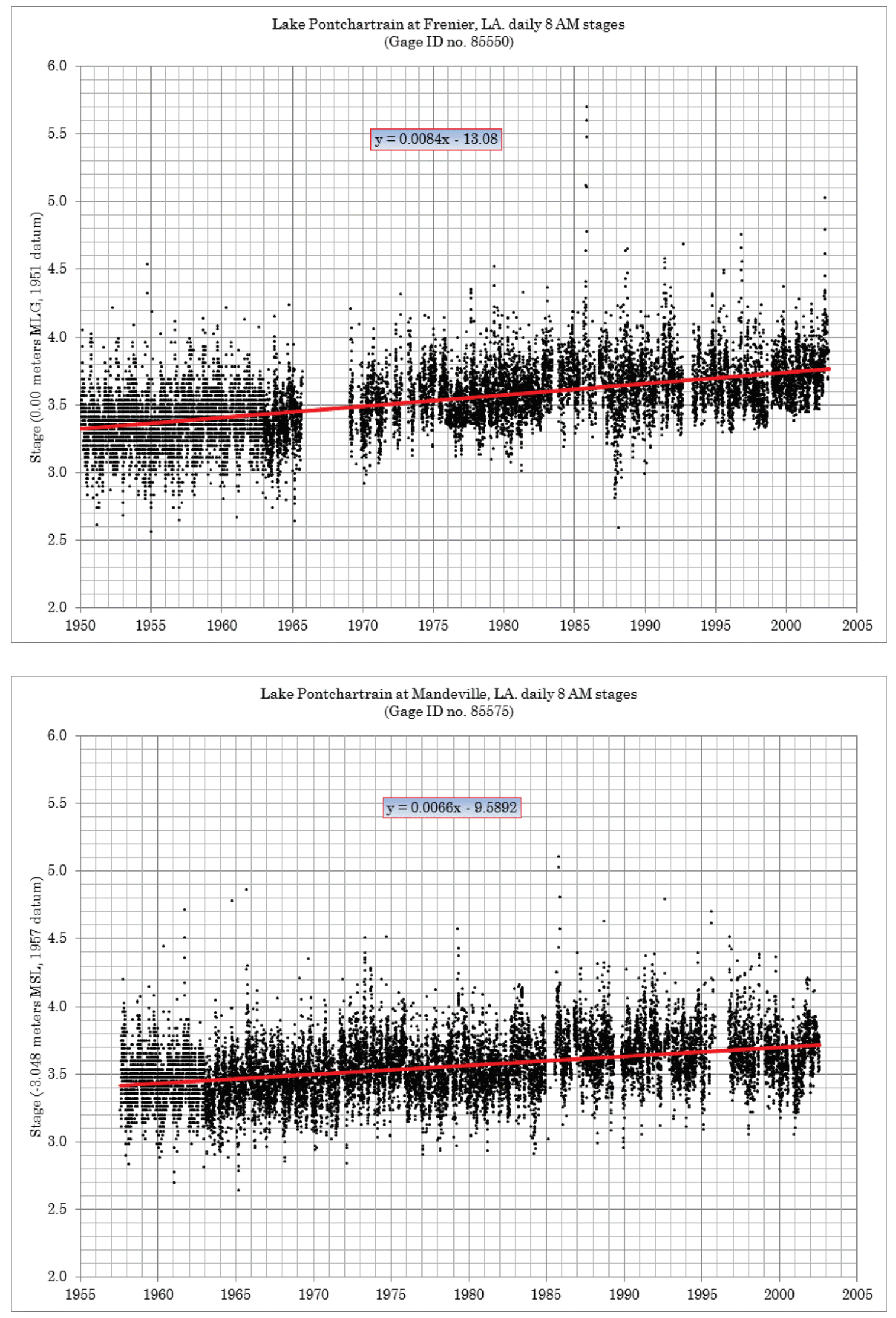

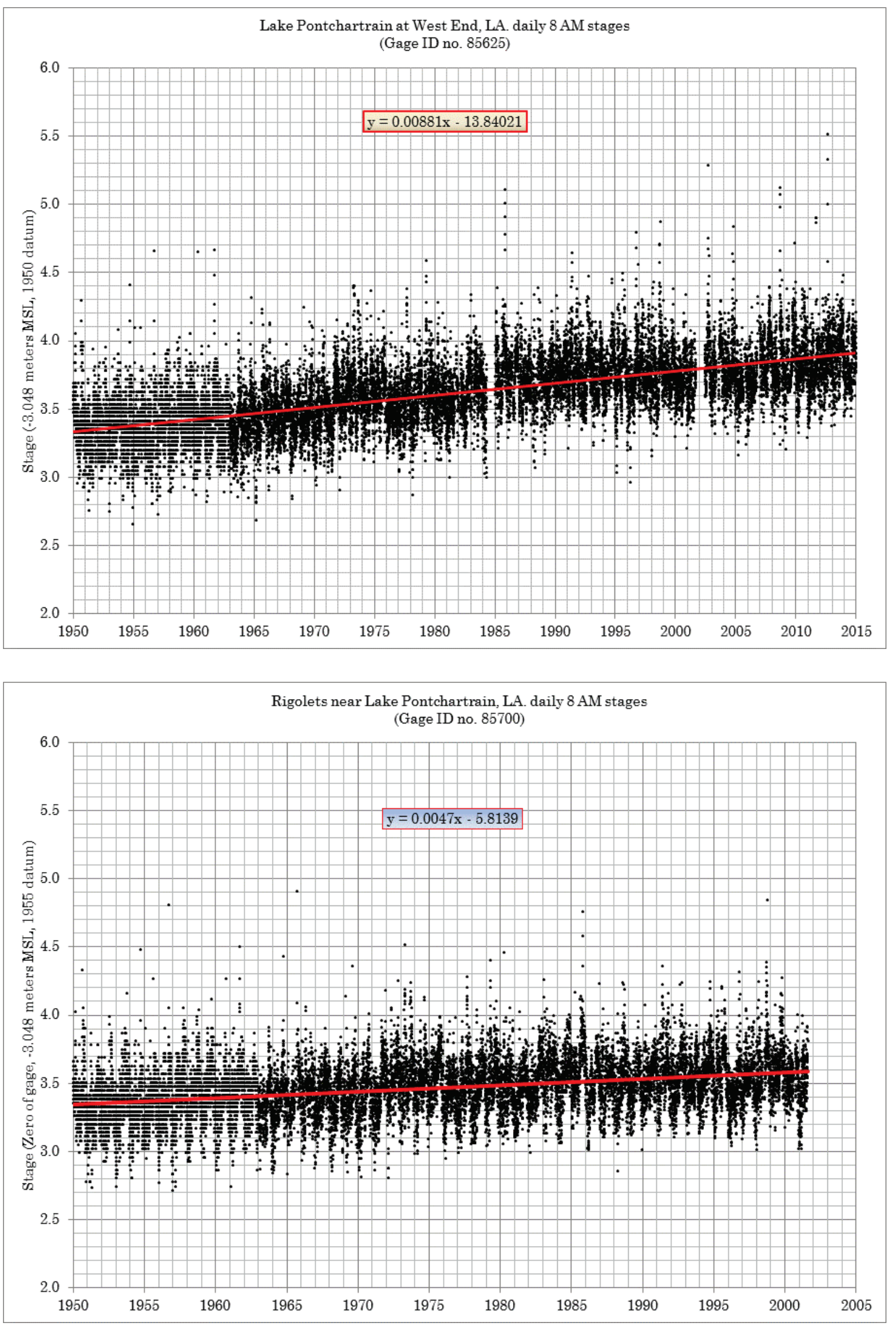

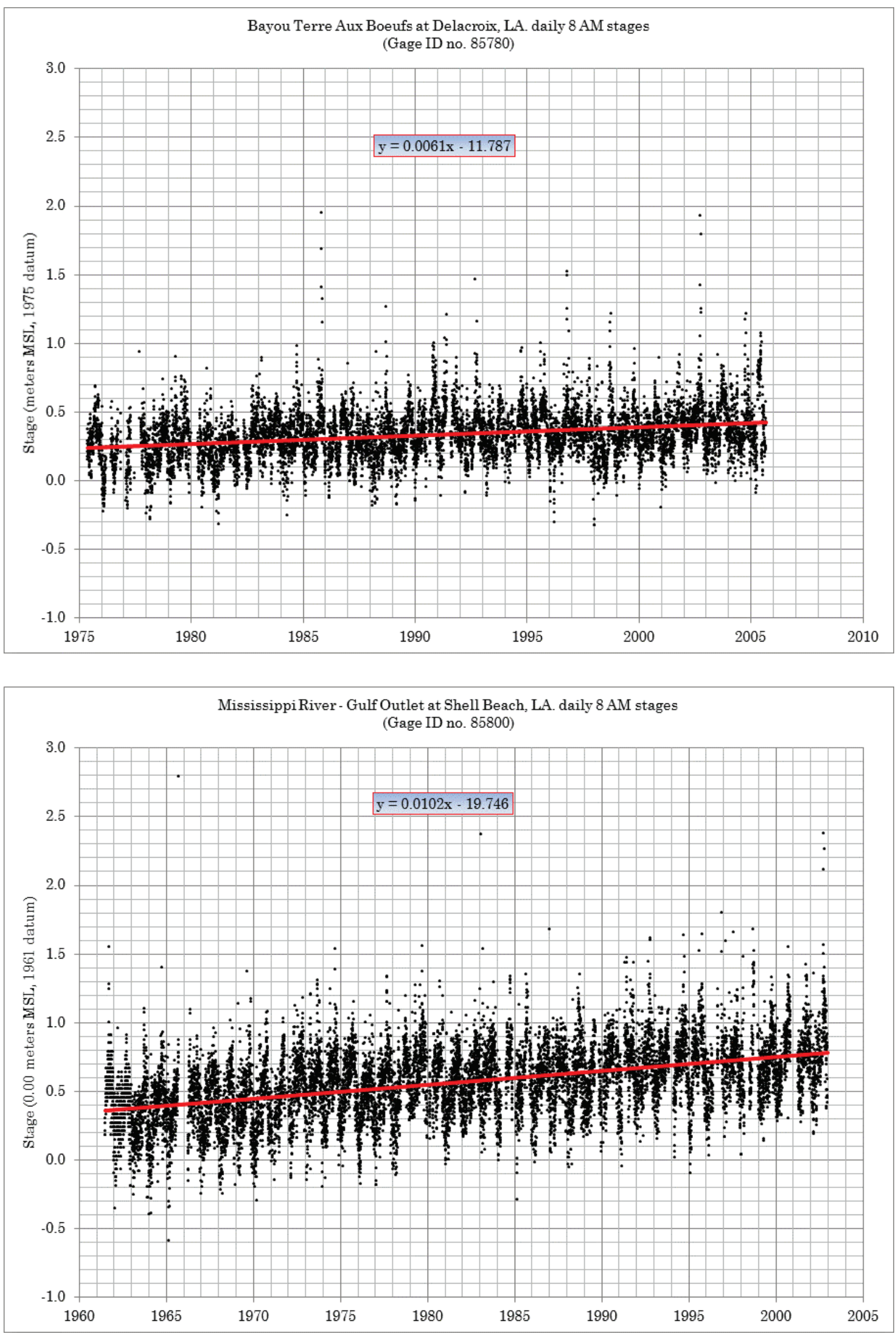


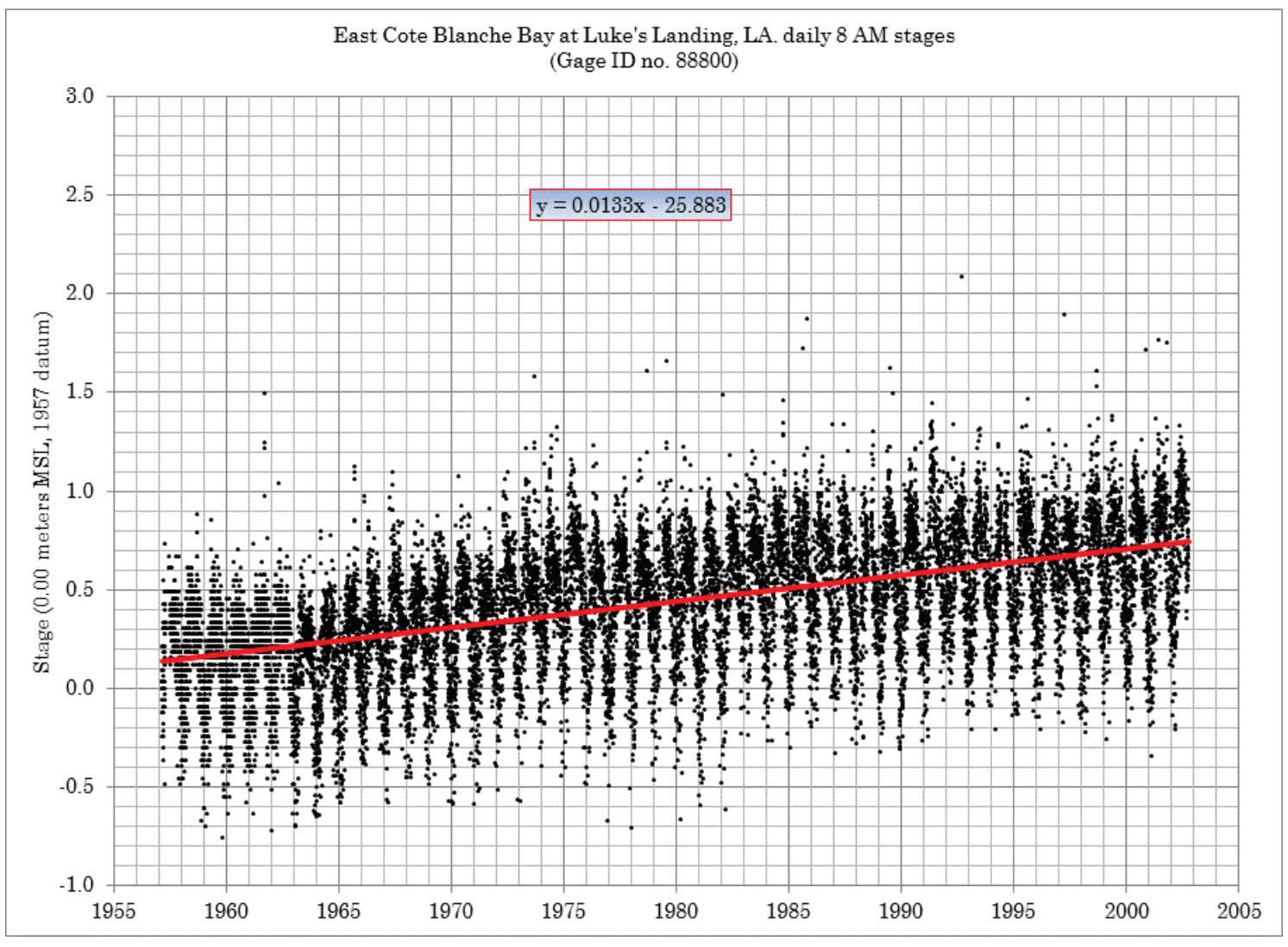




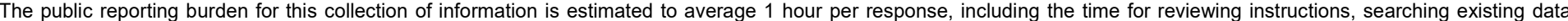

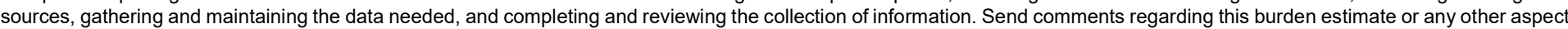

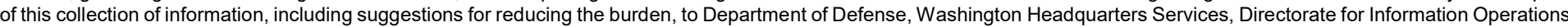

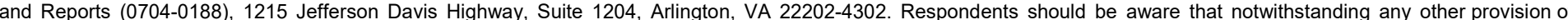
law, no person shall be subject to any penalty for failing to comply with a collection of information if it does not display a currently valid OMB control number.

PLEASE DO NOT RETURN YOUR FORM TO THE ABOVE ADDRESS.

\begin{tabular}{l|l|l}
\hline $\begin{array}{l}\text { 1. REPORT DATE } \\
\text { November } 2017\end{array}$ & 2. REPORT TYPE & 3. DATES COVERED (From - To) \\
& Final Report & \\
\hline
\end{tabular}

\section{TITLE AND SUBTITLE}

2015 Updated Atlas of U.S. Army Corps of Engineers Historic Daily Tide Data in Coastal Louisiana

\section{5a. CONTRACT NUMBER}

5b. GRANT NUMBER

5c. PROGRAM ELEMENT NUMBER

5d. PROJECT NUMBER

127672

5e. TASK NUMBER

5f. WORK UNIT NUMBER

8. PERFORMING ORGANIZATION REPORT NUMBER

MRG\&P Report No. 14

10. SPONSOR/MONITOR'S ACRONYM(S)

MVD

11. SPONSOR/MONITOR'S REPORT

NUMBER(S)
U.S. Army Corps of Engineers, Mississippi Valley Division

Mississippi River Geomorphology and Potamology Program

1400 Walnut Street

Vicksburg, MS 39180

\section{PERFORMING ORGANIZATION NAME(S) AND ADDRESS(ES)}

7400 Leake Avenue

12. DISTRIBUTION/AVAILABILITY STATEMENT

Approved for public release; distribution is unlimited.

\section{SUPPLEMENTARY NOTES}

\section{ABSTRACT}

In 2010, data were analyzed from 19 U.S. Army Corps of Engineers (USACE) gages to develop the USACE Tide Gage Atlas for Coastal Louisiana. The purpose of this document was to develop a useful tool for analyzing the sea level change trends in the coastal areas of Louisiana, where some of the highest relative sea level rise rates in the United States are observed (because of the significant subsidence in this region). The data were referenced to a common gage datum, analyzed for shifts, and any known adjustments removed. This 2015 update revised five of the nineteen original gages by extending the record of gage data and reapplying the linear trend. Eleven new gages were added, expanding the atlas to a total of thirty gages. The new data were evaluated in the same manner as the previously studied gages: adjustments were made to remove shifts in the data, river discharge influences were removed where necessary, and linear trends were applied. Continuous revisions of the atlas are intended to not only keep sea level change trends updated but also to expand data resources for ongoing and future projects.

\section{SUBJECT TERMS}

Coasts_-Louisiana, Data collection platforms, Sea level, Tide-gages

\section{SECURITY CLASSIFICATION OF:}

\begin{tabular}{l|l|l|}
\hline a. REPORT & b. ABSTRACT & c. THIS PAGE \\
Unclassified & Unclassified & Unclassified \\
\hline
\end{tabular}

\section{LIMITATION OF} ABSTRACT

SAR 18. NUMBER OF
PAGES

40 19a. NAME OF RESPONSIBLE PERSON Will Veatch

19b. TELEPHONE NUMBER (Include area code) 504-862-2858 